\title{
Nicholas of Methone, Procopius of Gaza and Proclus of Lycia
}

\author{
Anna Gioffreda \\ Österreichische Akademie der Wissenschaften \\ and \\ Michele Trizio \\ Università di Bari
}

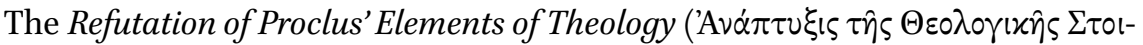

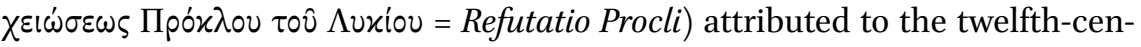
tury Byzantine theologian Nicholas of Methone (died between 116o-1166) is an important witness to the circulation and reception of Proclus' work in eleventh- and twelfth-century Byzantium.* The work analyses the text of Proclus' Elements of Theology from the point of view of twelfth-century Byzantine orthodoxy and provides for each topic discussed by Proclus its Christian counterpart. ${ }^{1}$ However, the paternity of this work has occasionally stirred some controversy as two fourteenth-century Vatican manuscripts ascribe two of the many sections composing this work to the late antique rhetor and theologian Procopius of Gaza (ca. 465/470-526/530 CE). The dispute appeared to be settled in 1984 with the publication of the editio princeps of Nicholas' work. ${ }^{2}$ However, recently, Eugenio Amato has defended again the Procopian authorship of the text in an erudite article that brings forth new historical and textual arguments favoring this view. ${ }^{3}$ Eventually Amato went further than this in editing the two sections of the Refutatio Procli ascribed to Procopius as authentic Procopian fragments. ${ }^{4}$ According to Amato, Nicholas of Methone

* Michele Trizio was responsible for drafting chapters 1-7; Anna Gioffreda for chapter 8. The conclusions were jointly written.

1 For a general presentation of the work, see Robinson 2014 and Robinson 2017. We would like to thank Joshua Robinson for reading an earlier draft of this essay.

2 Angelou 1984.

3 Amato 2010a.

4 Procopius of Gaza, Opuscula rhetorica et oratoria.

(C) KONINKLIJKE BRILL NV, LEIDEN, THE NETHERLANDS, 2021 | DOI:10.1163/9789004440685_006 
appropriated an earlier Procopian work for purely rhetorical purposes and without declaring his source. ${ }^{5}$

But is it really so? Did Nicholas-one of the most important twelfth-century theologians - shamelessly appropriate a text that he (and evidently his contemporaries as well) knew as Procopius' without fearing detection? Are the two fragments of the Refutatio Procli attributed to Procopius all that is left of a polemical work against Proclus written by the scholar of Gaza? And, if so, why does the attribution to Procopius only appear in the second half of the fourteenth-century? Who is the late Byzantine scholar who ascribed to Procopius sections 139 and 146 of the Refutatio Procli in the Vatican manuscripts, and why was he interested in this text? Contrary to what has been done so far, this article addresses this dispute from a multidisciplinary approach, using text-criticism, paleography and history of culture and education. In this way we are confident of reaching inasmuch as possible, if not a definitive argument, at least a probable one on this issue.

\section{Nicholas Reloaded:The Modern Debate on the Refutatio Procli}

To start, we would like to briefly summarize the earlier debate on the authorship of the Refutatio Procli. ${ }^{6}$ It all began in 1825 when the German philologist Johann Theodor Voemel published the first modern edition of the Refutatio Procli under Nicholas of Methone's name. ${ }^{7}$ In 1893, however, Demetrios Roussos noticed that ch. 146 of Nicholas' Refutatio Procli was identical to a fragment attributed to Procopius in a Vatican manuscript edited by Cardinal Angelo Mai in $1831 .{ }^{8}$ At this point, after composing three articles on the Refutatio Procli as Nicholas' authentic work, ${ }^{9}$ the German philologist Draeseke changed his mind and published in 1895 a sensational article accusing Nicholas of plagiarism. According to Draeseke, the Refutatio Procli should be regarded as a Procopian work plagiarized in its entirety by Nicholas. ${ }^{10}$ This allegation has been widely accepted by Procopian scholars despite the fact that in 1899 Stiglmayr published a refutation of Draeseke's view that rigorously supported Nicholas' authorship of the Refutatio Procli. ${ }^{11}$ Thus, while most scholars accept

5 Amato 2014, p. XI-LXXXV.

6 For a precise reconstruction of the debate, see Robinson 2014, p. 44-72. We take the opportunity to thank Joshua Robinson for sharing his work with us.

$7 \quad$ See Voemel 1825 . On this publication, see Jeck 2015.

8 Roussos 1893; Mai 1831, p. 247.

9 Draeseke $1888 ; 1891 ; 1892$.

$10 \quad$ Draeseke 1895; 1897.

11 Stiglmayr 1899. 
Nicholas' authorship of the text, several specialists on Procopius doggedly adhere to the Procopian paternity of the Refutatio Procli, although none have ever really demonstrated proof. ${ }^{12}$ Moreover, the supporters of the Procopian authorship have never confronted Stiglmayr's arguments. In fact, these demonstrate that, if attributed to Procopius, the text of the Refutatio Procli would contain a great amount of anachronism and adynata, sources such as Ps.Dionysius the Areopagite, John of Damascus, Photios etc., whom Procopius could not possibly know. In other words, after Stiglmayr the thesis that Nicholas plagiarized an earlier Procopius work in its entirety could no longer be defended.

In 1931 Giovanni Mercati published his monumental volume on the fourteenth-century Byzantine controversy known as 'the hesychast controversy'.13 For reasons which will be explained later, he dealt with the fragments in the Vatican manuscripts which ascribe chapters 139 and 146 to Procopius. Mercati accepted Stiglmayr's arguments against the plagiarism thesis, but whereas Stiglmayr thought the attribution to Procopius was a wrong conjecture by the scribe of the Vatican fragments, Mercati believed that, on the contrary, the scribe inherited the attribution to Procopius from his model and that, therefore, he cannot be blamed for unskillfulness. According to Mercati, at a certain point chapter 139 and 146 circulated under the name of Procopius independently from the rest of the Refutatio Procli ascribed to Nicholas in the extant tradition of the text. ${ }^{14}$

That is why Amato's recent reassessment of the issue is a welcome contribution to the discussion. For the first time, a Procopian scholar admits the Procopian authorship of the text without implying that the whole Refutatio Procli ascribed to Nicholas is a plagiarized work. In fact, Amato defends that the Refutatio Procli is an authentic work by Nicholas which nonetheless elaborates on an earlier text by Procopius. ${ }^{15}$ On this basis Amato explains the existence of the Vatican fragments attributing chapters 139 and 146 to Procopius alone: these fragments are all that are left of a Procopian Refutation of Proclus' Elements of Theology later re-elaborated by Nicholas of Methone. Amato also insists on a reference by Choricius of Gaza, one of Procopius' disciples, to his master's

12 See e.g. Aly 1957, p. 271; Chauvot 1986, p. 87-88; Matino 2005. To be fair, the thesis of the Procopian authorship of the Refutatio Procli has also been accepted by the authoritative Krumbacher $1897^{2}$ and by Tatakis 1949, p. 38 .

13 Mercati 1931, p. 264-266. On the controversy, see Russell 2017.

14 Mercati 1931, p. 264-266.

15 Amato 2010a, p. 11-12. 
commitment to refute the heresies as a proof favoring Procopius' authorship of the Refutatio Procli, ${ }^{16}$ and on two testimonia favoring the existence of a Procopian refutation of Proclus' commentary on the Chaldean Oracles (more on this later). ${ }^{17}$ In his view, these testimonia make the existence of a Procopian Refutatio Procli more than probable. Accordingly, the copyist of the two Vatican manuscripts was the last scholar having access to one or even more redactions of a now-lost Refutatio Procli penned by Procopius of Gaza.

Overall, Amato's erudite solution to the controversy appears to be a reasonable one which reconciles the Procopian authorship of the Refutatio Procli and Nicholas of Methone's role in the tradition of the text. However, Amato's view currently struggles to gain adherents outside the circle of Procopian specialists. Proof of this is the fact that the fragments ascribed to Procopius in one of the Vatican manuscripts have been recently treated once again as PseudoProcopius by Ioannis Polemis ${ }^{18}$ in his edition of a fourteenth-century theological treatise attributed by Mercati ${ }^{19}$ to the Byzantine scribe and scholar Isaak Argyros and tentatively attributed to John Kyparissiotes by the same Polemis. ${ }^{20}$ However, it is also true that the Vatican fragments ascribed to Procopius have been included in the TLG online, though the text is reproduced according to Mai's edition instead of Amato's version.

We can already point out for the reader's benefit that Isaak Argyros, the fourteenth-century hesychast or Palamite controversy, and the two Vatican manuscripts ascribing chapters 139 and 146 of the Refutatio Procli to Procopius are key elements of this complex story. We believe that by reviewing the available data and by unearthing new evidence we can still make progress in the reconstruction of this complex matter. We will first discuss Amato's arguments favoring the existence of an earlier Procopian refutation of Proclus' Elements of Theology, then we will present some new findings on the Vatican manuscripts preserving the fragments of the Refutatio Procli under Procopius' name, and finally we will propose our solution to this intricate matter.

\footnotetext{
16 Choricius, Opera, 8.1.21, 117.19-22.

17 Cf. infra p. 101-102.

18 See Polemis 2012, p. LXXviI. To be fair, elsewhere in his edition Polemis attributes the fragments to Procopius without further elucidation.

19 Mercati 1931, p. 241.

20 Polemis 2012, p. LIII-LVIII.
} 
In our view the previous debate on the authorship of the Refutatio Procli has been often limited by:

1) The reluctance to take into account the twelfth-century Byzantine intellectual history and the circulation of Proclus' work in this period. None of the supporters of the Procopian authorship of the Refutatio Procli seem to be aware that Neoplatonism, and in particular Proclus' work, had a tremendous impact on eleventh- and twelfth-century Byzantine scholars. ${ }^{21}$ This bias is evident, for instance, in Amato's claim that Nicholas' Refutatio is a mere rhetorical piece with no relationship with the theological and philological literature of the time. ${ }^{22}$

2) The reluctance in engaging seriously the tremendous amount of philological and historical arguments favoring Nicholas' paternity of the Refutatio Procli brought forward by Stiglmayr and Angelou. Even if we accept Amato's more sophisticated thesis that Nicholas appropriates and reelaborates an earlier Procopian text, the elements in the text pointing to a middle Byzantine dating of the Refutatio are so many and so relevant that one may fruitfully wonder what is left of this alleged earlier Procopian work. In this regard even Amato's reintroduction of the plagiarism theory does not seem to dispel the ambiguity. ${ }^{23}$ As a matter of fact Amato's thesis leads to the paradoxical view that in composing the Refutatio Nicholas generally re-elaborated on an earlier work and introduced new elements of his own everywhere, with the exception of chapters 139 and 146 , which are to be regarded as authentically Procopian texts. ${ }^{24}$ By contrast, we believe that in order to make their case stronger the supporters of the Procopian authorship of the Refutatio Procli must identify stylistic features or doctrines in the text that could only be explained by referring to a fifth-century text. In this regard, even if we accept Amato's more sophisticated view, Stiglmayr's arguments still hang as a sword of Damocles above the supporters of the Procopian authorship of the Refutatio Procli.

3) The insistence by supporters of the Procopian authorship of the Refutatio Procli on relying for defending their view on two articles by Westerink and Whittaker, published in 1942 and 1975 respectively, whereas none of these

\footnotetext{
21 Cf. infra p. 108-114.

22 Amato 2014, p. XI-LXXXV.

23 Amato 2014, p. Xxx.

24 Amato 2010a, p. 7.
} 
articles has ever touched upon this issue. ${ }^{25}$ In the first article, Westerink provided slight evidence favoring the existence of a Procopian refutation of Proclus' commentary on the Chaldean Oracles, namely a late scholion to Lucian's Philopseudes (119.17) and a text of eleventh-century polyhistor Michael Psellos, ${ }^{26}$ more on which later. As to Whittaker, nowhere does he demonstrate the existence of a lost Procopian Refutation of Proclus' Elements of Theology, but simply suggests that Psellos got his information on Procopius' alleged refutation of the Oracles not from Procopius himself, but rather from an intermediate commentary on Gregory the Theologian.

4) The reluctance to address the state of the fragments attributed to Procopius in the Vatican manuscripts, the method of the scribe, and finally the circulation of these fragments. By contrast, we believe that a close inspection of the manuscripts preserving the fragments and a review of the scribe's modus operandi can be of great help for establishing the origin and circulation of the fragments themselves, including the attribution to Procopius of chapters 139 and 146. As a matter of fact, unknown to Amato, such an attempt has already been pursued by Daniele Bianconi. ${ }^{27}$ In this paper we are going to expand on Bianconi's findings.

We must begin by briefly discussing the arguments supporting the Procopian authorship of the text. Most of them cite external evidence suggesting the plausibility of the attribution to Procopius of an otherwise lost Refutatio Procli. To start with, supporters of the Procopian authorship of the Refutatio Procli remind us that Procopius' work has come down to us in fragmentary form. Of the many works authored by Procopius and praised by Photios as "many and diverse" ( $\pi 0 \lambda$ oi $\tau \varepsilon$ k $\alpha i \pi \alpha \nu \tau 0 \delta \alpha \pi 0 i)^{28}$ only a few survive, and because of this one cannot exclude the possibility that Procopius ever authored a text such as the Refutatio Procli. However, we believe that the Patriarch's words cannot be used as a sort of nihil obstat argument favoring the existence of a lost Procopian work. ${ }^{29}$ If, on the one hand, Photios' praise of the expansive breadth of Procopius' literary output encourages the supporters of the Procopian authorship,

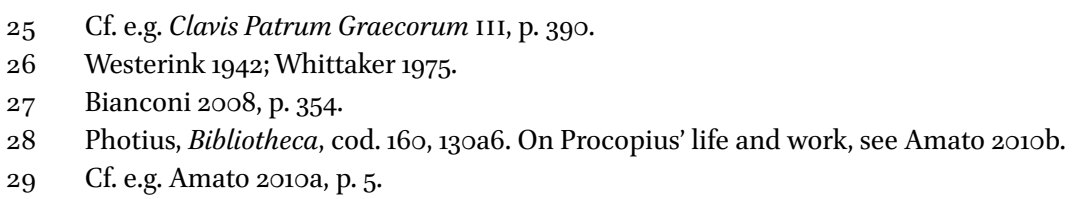


then, on the other hand, it must be said that when examining Procopius' works available to him, Photios only mentions Procopius' Commentary on Octateuch, Kings, Chronicles and Isaiah. ${ }^{30}$ The well-informed patriarch makes no mention of a Procopian Refutatio Procli nor does he ever suggest that such a work existed.

More importantly, Choricius-insist the supporters of the Procopian authorship of the Refutatio Procli-tells us that Procopius embarked upon the refutation of heresies as well. Also this witness makes it theoretically plausible that Procopius authored a work like the Refutatio Procli, but actually does not prove it, because Choricius only says that Procopius devoted himself "to

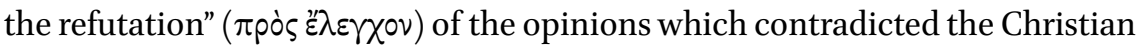
dogma, without further clarifying whether these included philosophical paganism or other Christian heresies. It is surely true that distinguished members of the school of Gaza engaged philosophical paganism (see for instance Zacharias Scholasticus' Ammonius, Aeneas of Gaza's Theophrastus and the Commentary on Genesis by the same Procopius), ${ }^{31}$ but it is also true that they engaged other

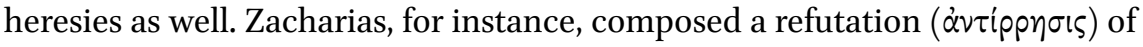
the Manichaeans.

Procopian scholars also cite other texts authored by eminent representatives of the so-called "school of Gaza" that underwent a process of appropriation or plagiarism by later Byzantine scholars. ${ }^{32}$ Of all arguments, this is probably the weakest one. In fact, none of the writings cited as parallel are actually by Procopius, but rather by his disciple, Choricius. More importantly, they are all rhetorical texts such as encomia or ekphraseis, i.e. they belong to a particular literary genre known for easily allowing later borrowings or even plagiarisims. Quite on the contrary, with regard to theological works such as the Refutatio Procli it is very hard to imagine that a prominent theologian like Nicholas could openly plagiarize or re-elaborate on a work which both he and his contemporaries knew as written by Procopius.

Nor is it possible to prove the Procopian authorship of the fragments by referring them to Procopius' Commentary on Genesis. In fact, chapters 139 and 146 deny the existence of divine causes other than God and explain the nature of the intratrinitarian procession in far too vague a manner to allow a connection with Procopius' Commentary. Procopius had no copyright on these issues, and actually these chapters summarize standard Christian beliefs commonly found in Patristic and Byzantine sources. In particular, the fragments simply

30 Photius, Bibliotheca, cod. 206-207, 164b-165a.

31 See Champion 2014, p. 71-195; Sorabji 2015, p. 71-93.

32 Amato 2010a, p. 8-10. 
rephrase Proclus' text in order to make it compatible with Christianity. ${ }^{33}$ In fact, as we shall elucidate later, it appears that the technical vocabulary of chapters 139 and 146 is reminiscent of middle-Byzantine theology.

We would also like to make a few incidental remarks on the testimonia for Procopius' writing against Proclus' Chaldean Oracles. The first testimony comes from Michael Psellos. The latter reports that Proclus is said to have called

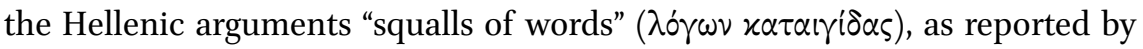
Procopius of Gaza. ${ }^{34}$ Since in another passage Psellos refers to the Chaldean Oracles and speaks of "the pagan Greek of our day", Westerink believed that here Psellos is quoting from a refutation of the Chaldean Oracles by Procopius. ${ }^{35}$ However, as Dominique O'Meara (the distinguished editor of Psellos' philosophical work) has elucidated, to connect these two texts is risky, since it is far from clear whether or not the second text, which is a summary used by Psellos elsewhere as well, actually excerpts from Procopius or from another as yet unidentified source of later date. ${ }^{36}$ Whittaker supported this latter view when suggesting the existence of a commentary on Gregory the Theologian containing this and other information. ${ }^{37}$ To this we shall add that in both passages where Psellos ascribes to Procopius the description of the Oracles as "squalls of words", Proclus is described by Psellos in enthusiastic terms, something which would be rather strange if we assume that here Psellos excerpts from Procopius' alleged Refutation of the Chaldean Oracles.

The second witness is a scholion to Lucian's Philopseudes (119.17) which reads:

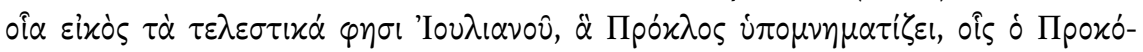

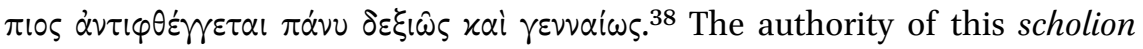
has been challenged by Kroll on the basis of its late dating and its absence

33 Unfortunately, the text edited by Angelou does not allow distinguishing between Nicholas' paraphrase of Proclus' text and Nicholas' own comments on it. Perhaps it would have been better to edit the former in italics in order to differentiate those passages where Nicholas is using and citing Proclus' text from those where he elaborates his own critique.

34 Michael Psellos, Orationes forenses et acta, 1, 12.293-294.

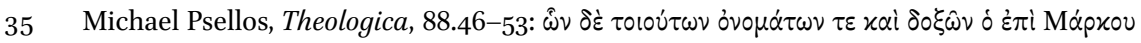

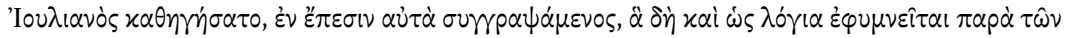

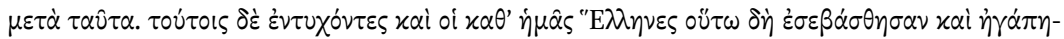

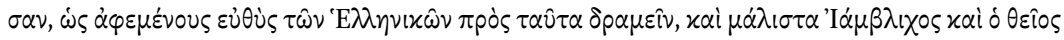

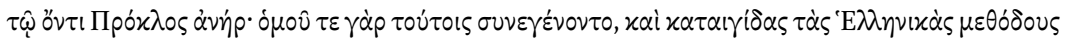

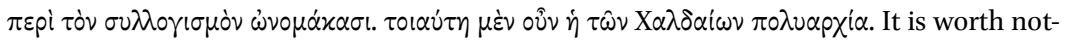
ing that this text echoes the description of the Greek demonstrations as "squalls of words"

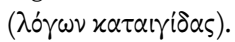

36 O'Meara 2013, p. 56.

37 Cf. supra p. 98-99.

38 Lucian of Samosata, Scholia, v. IV, 224-225. 
in the earlier and more important manuscripts of Lucian's work. ${ }^{39}$ Westerink prudently recalled, however, that it is theoretically possible for the scholion to be an excerpt from an earlier authoritative source. ${ }^{40}$ Eager to test Westerink's suggestion, we decided to investigate this matter further. As a result of this, we realized that the manuscript which purportedly transmits the scholion is the now lost codex Graevii, a manuscript which Graeve used for his seventeenthcentury edition of Lucian. While it is not possible to detect information from a direct study of the manuscript itself, it is nevertheless possible to trace the text of this scholion, at least tentatively, back to its possible source or to the context in which it originated. This is what Martin Sicherl did in an article published in 1960. Sicherl brought forth convincing arguments suggesting that the scholion goes back to the very source of the first testimony for Procopius' writing against Proclus' Chaldean Oracles mentioned above, namely the same Michael Psellos, who in fact is known for having read Lucian's Philopseudes. ${ }^{41}$ The consequence of this finding is that we do not have anymore two distinct and independent witnesses to Procopius' refutation of Proclus' commentary on the Chaldean Oracles, but rather only one, the aforementioned Psellos. Whether the latter had access to this Procopian work or only to a later source (as suggested by Whittaker and O'Meara) is still matter of debate and is not relevant to the scope of the present paper. What is pretty clear is that there is no way this tenous evidence favoring the existence of a Procopian refutation of Proclus' scholarship on the Chaldean Oracles can be used to demonstrate the existence of a Procopian Refutation of Proclus' Elements of Theology.

Sources and Stylistic Pattern of the Fragments

Then come Stiglmayr's arguments. For the sake of brevity, we cannot comprehensively detail Stiglmayr's arguments, but we will focus on a few that also allow us to introduce new evidence. For instance, Stiglmayr references Trinitarian language as proof for a twelfth-century dating. This reveals the distinctive trace of John of Damascus' and Photios' Trinitarian speculation and a strong

39 In Paulys Realencyclopädie der classischen Altertums Wissenschaft, $\mathrm{x}$, col. 15. Actually the scholion has not been included by Rabe in his 1906 edition of the scholia to Lucian's work (Rabe 19o6).

40 Cf. Westerink 1942, p. 276-277.

41 Sicherl 196o, in part. p. 18-19. This might well explain why the scholion at hand is not found in the earlier ninth-tenth-century manuscripts preserving Lucian's works, namely because it originated in a later source such as Psellos. 
emphasis on the procession of the Spirit ex solo Patre typical of the anti-Latin theological literature of which Nicholas is an eminent figure..$^{42}$ In what follows we shall corroborate Stiglmayr's findings and we shall provide further internal evidence suggesting that 1 ) chapters 139 and 146 are consistent with the rest of Nicholas' Refutatio Procli and that 2) the language in these chapters reveals a theological concern that hardly fits within the view of the Procopian authorship of the Refutatio Procli.

The first example comes from the refutation of prop. 22 of the Elements of Theology (section 22 of the Refutatio Procli): "All that exists primally and originally in each rank is one, and not two or more than two, but unique" (П⿵人丶

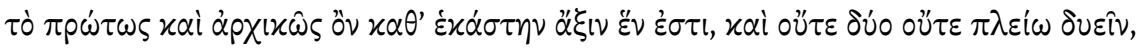
$\alpha \lambda \lambda \dot{\alpha} \mu \circ v 0 \gamma \varepsilon v \varepsilon \dot{\varepsilon} \varsigma \hat{\alpha} \nu) .{ }^{43}$ Before embarking upon the refutation of the proposition at hand, Nicholas remarks: "and thus someone might even use this proposition against the Latins, who say that the Spirit has two principles, Father and Son"

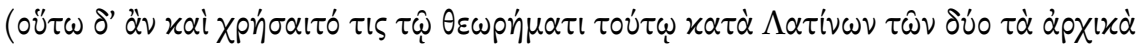

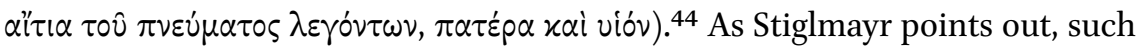
a statement can only be understood in the context of the Filioque controversy which led to the great schism of $1054 \cdot{ }^{45}$ Nicholas, who engaged the Filioque thesis at length, knew it terribly well.

To Stiglmayr's remark, we shall add that in one of his anti-Latin treatises Nicholas summarizes the Latin position as follows:

For this reason, if the Father and the Son are one and they are one also in nature, one must concede that just as [the Spirit] proceeds from the Father, so it proceeds from his Son (in fact this is the mistake implied in the innovation introduced in the Latin dogma).

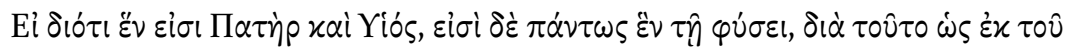

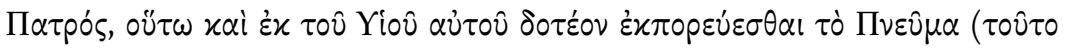

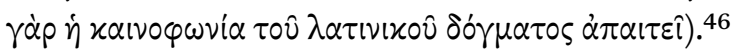

A similar text is found in Nicholas' treatise on the Holy Spirit addressed to the megas domestikos:

\footnotetext{
42 Stiglmayr 1899, p. 289-293.

43 Nicholas of Methone, Refutation of Proclus' Elements of Theology, p. 30.14-15.

44 All English translation of Nicholas' Refutatio Procli are by Robinson (2014), with slight modifications. The English text of Proclus' Elements of Theology is that by Dodds.

45 See Stiglmayr 1899, p. 29o. On the Filioque see Siecinski 2010.

46 Bibliotheca ecclesiastica, p. 363.7-10.
} 
For because of this we will neither say that the Spirit is a divine indwelling, nor that it proceeds from the Son, which is the Latin madness.

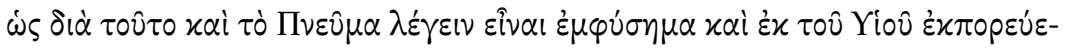

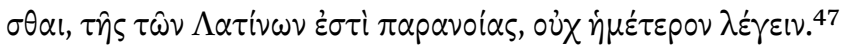

Indeed, one may fruitfully recall that Amato's thesis takes into account these anachronisms and explains them as resulting from Nicholas' re-elaboration of Procopius' Refutatio. But if we look at chapter 146, which in Amato's view is authentically Procopian, we read that:

Only the begetting of the Son from the one and only Father and [the] projection from the same of the one and only Holy Spirit would be called a divine procession without beginning and without end, [the begetting and the procession] according to which the paternal and original, or rather pre-original Monad, moved toward the Dyad, which is beheld in the Son and the Spirit, and at the Trinity come to a halt, as our theologian Gregory says

Or. 29.2, $P G$ G6, $76 \mathrm{~B}$

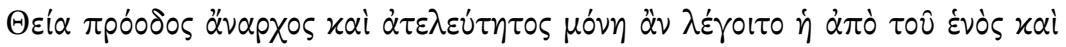

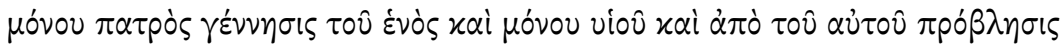

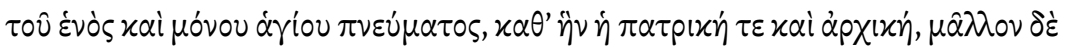

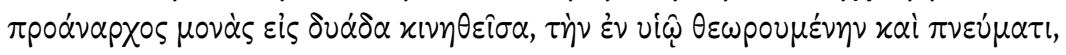

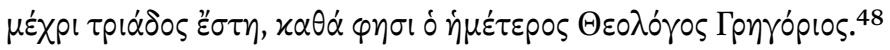

This text and the quotation from Gregory in it have been regarded as a key argument in previous scholarship on the Refutatio Procli. For instance, it prompted Whittaker to suggest a link with the commentary tradition on Gregory of Nazianzus. ${ }^{49}$ And yet, we totally agree with Stiglmayr that the first lines of the text unmistakably cast the citation from Gregory within the frame of the middle Byzantine theory of the procession of the Spirit ex solo Patre and of the theological dispute with the Latins. ${ }^{50}$ Furthermore, it should be noted that the word $\pi \rho \dot{\beta} \beta \lambda \eta \sigma \iota \zeta$, here "procession", is extremely rare and never appears in Patristic texts as referring to the procession of the Spirit. The only other

$47 \quad$ Bibliotheca ecclesiastica, p. 212.5-6.

48 Nicholas of Methone, Refutation of Proclus' Elements of Theology, p. 133.22.

49 Whittaker 1975, p. 313.

50 Stiglmayr 1899, p. 297. 
occurrence is in section 7 of Nicholas' Refutatio Procli. ${ }^{51}$ This suggests that the author of section 146 is the same as the author of section 7 . The fact that in section 7 the author casts the term $\pi \rho \delta \beta \lambda \eta \sigma ı$ within the technical Byzantine distinction between the generation of the Son and the spiration of the Spirit is consistent with Stiglmayr's idea that the author is not a late-antique one.

In other words, right from the beginning of the "authentically" Procopian fragment of chapter 146 one finds an element which cannot be Procopian. By contrast, it belongs to the Middle Byzantine anti-Latin controversy and is consistent with the other passages from Nicholas' Refutatio Procli and his anti-Latin treatises. In particular, the first sentence of chapter 146 connects with section 22 of the Refutatio Procli, where Nicholas questions the Latin Filioque as a case of causation by two principles (the Father and the Son), instead of the Father alone. Furthermore, no one seems to have noticed that the above-mentioned citation from Gregory appears in other sections of the Refutatio Procli and is explained by Nicholas with the theological vocabulary typical of Byzantine theology after Photius. See, for example:

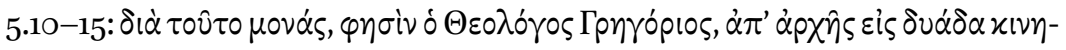

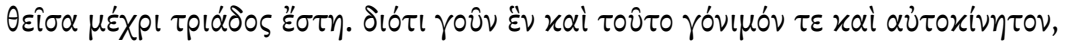

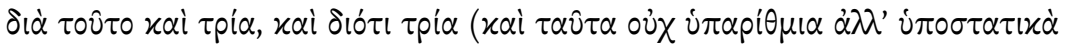

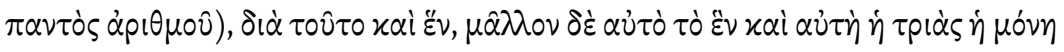

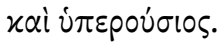

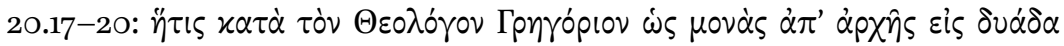

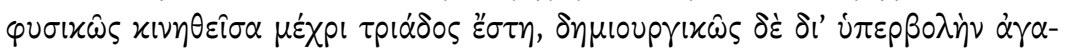

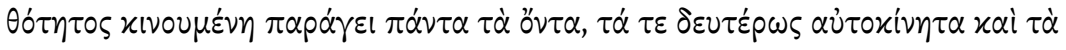

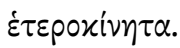

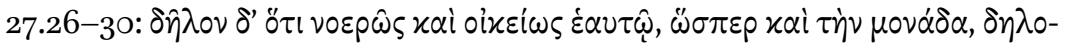

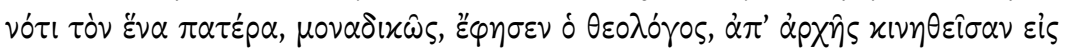

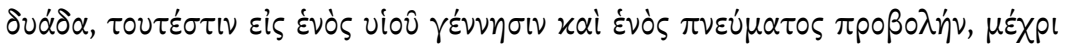
$\tau p \dot{\alpha} \delta$ os $\sigma \tau \hat{v} \nu \alpha l$.

Indeed, supporters of the existence of a Procopian Refutatio Procli might argue that Nicholas took this citation from the Procopian version of chapter 146 and used it elsewhere in the Refutatio. Alternatively, they might argue that the pres-

$5^{1} \quad$ Nicholas of Methone, Refutation of Proclus' Elements of Theology, p. 7, 11,19. 
ence of the citation from Gregory belongs to the residual part of the text which Nicholas incorporated into his own version of the text. Such an argument would be to no avail. In fact, we have demonstrated that chapter 146 presents the Gregory passage as supporting the typically Byzantine procession of the Spirit ex solo Patre. Therefore, chapter 146 can no more be regarded as a Procopian text and, if this is the case, neither can the other sections of the Refutatio Procli where the citation from Gregory appears. On the contrary, the presence of Gregory throughout the Refutatio Procli ascribed to Nicholas suggests a consistent pattern. Furthemore, the frequent use of this very same Gregory passage in the other anti-Latin writers and Byzantine theologians confirms the pattern as well. ${ }^{52}$ Nicholas himself is among these writers of anti-Latin treatises, which is evidenced by:

Niketas Stethatos, Contra Latinos et de processione spiritus sancti, ed.

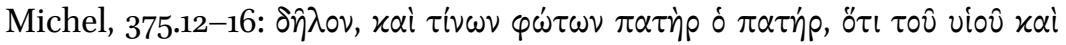

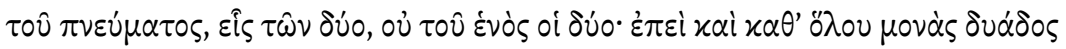

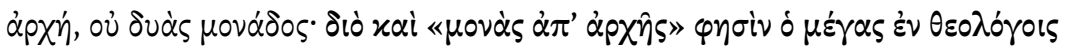

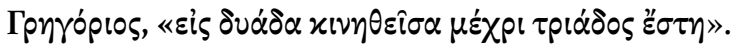

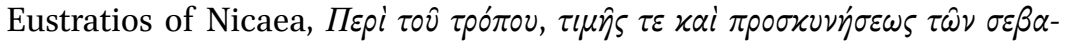

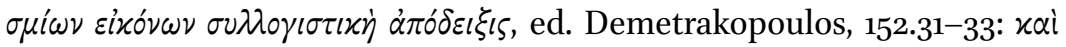

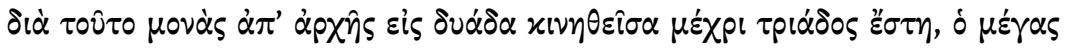

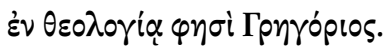

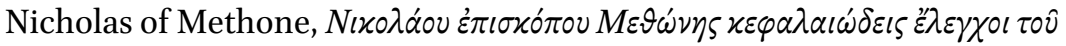

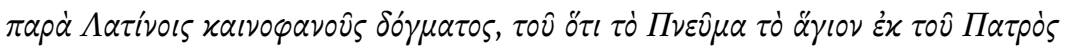

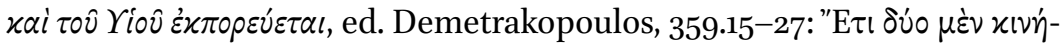

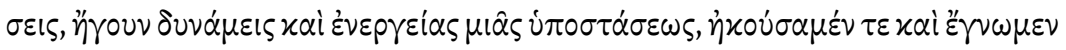

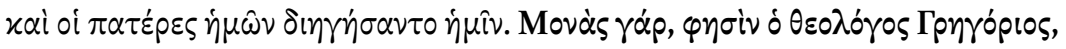

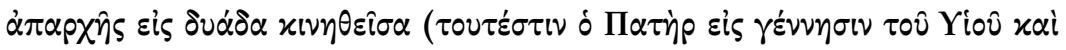

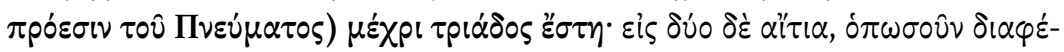

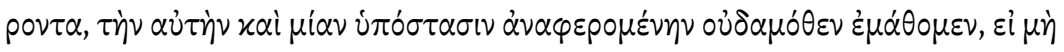

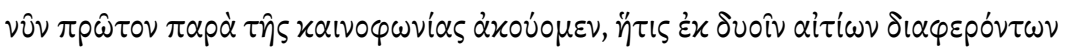

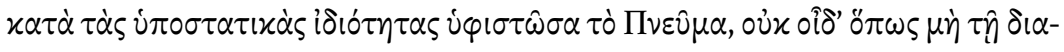

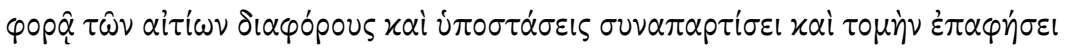

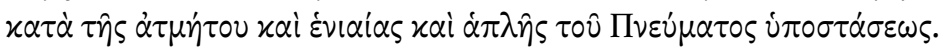


This latter text is particularly interesting in that in it Nicholas links the Filioque to a procession from two causes rather than one. This is exactly his aim in chapters 22 and 146 of the Refutatio Procli: ascribing the divine procession to one and the same cause, namely the Father, and excluding that other principles, such as the Son, can be cause the way the Father is cause in the proper sense. Thus, the first lines of chapter 146 are pretty much consistent with the anti-Filioquist undertones in the rest of the Refutatio Procli.

While looking for stylistic features of the Refutatio Procli ascribed to Nicholas we realized that just as he cites Gregory in chapter 146 , so does he consistently in the rest of the Refutatio. ${ }^{53}$ This suggests once more the existence of a common stylistic pattern between chapter 146 and the rest of the Refutatio Procli. However, since we have demonstrated that in chapter 146 the quote from Gregory reflects Nicholas' anti-Latin concerns, it would not be possible to consider this and the other citations from Gregory as residual elements of Procopius' alleged Refutatio.

Another passage supports the consistency between ch. 146 and the rest of the Refutatio Procli, reading:

by contrast, the procession according to illumination proceeds thence as perpetual and without end, bestowing to some in first distribution, to others in second distribution and so forth, as the divine effulgences pour forth according to transmission in correspondence with the ranks or stations of each, even to the last ones among them.

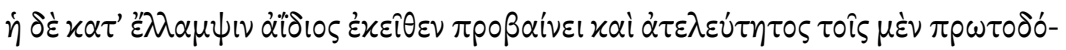

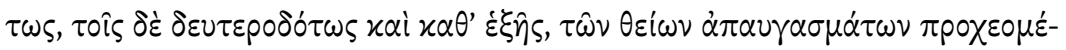

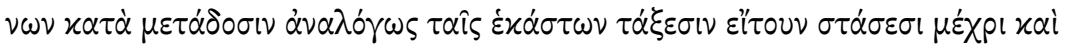

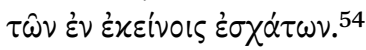

This text reflects a passage from ch. 70:

if every illumination from above proceeds from the one and first principle, it is plainly evident that nothing of the things after the first principle projects its own illumination to the things after it, but rather, that

53 Nicholas of Methone, Refutation of Proclus' Elements of Theology, p. 5.11; 12.31-32; 14.2728; 17.5-7; 20.17-18; 22.21-22; 25.19-21; 26.30-27.1; 27.28.28; 41.3-5; 49.2; 59.16-17; 89.16-17; 101.2O-21; 117.11-12; 133.20-21; 137.17-18; 146.2-3; 149.15; 149.22-26; 152.30-153.1; 168.23-25; $174 \cdot 7-8$.

54 Nicholas of Methone, Refutation of Proclus' Elements of Theology, p. 134-7-10. 
which is immediately after the principle, since it has illumination from that primary-giving, transmits this to those after it by secondary-giving.

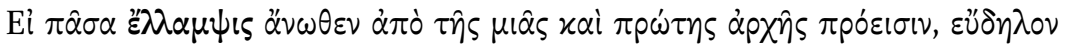

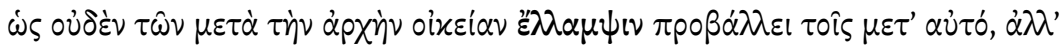

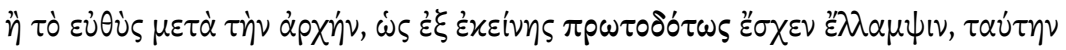

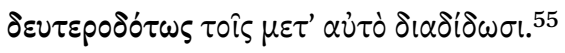

This as well as the previous textual parallels are consistent with the hypothesis that the Refutatio Procli has been written by one and the same author and that this author is Nicholas.

\section{A Historian's View}

Another argument against the attribution of the Refutatio Procli to Nicholas alone is that to compose such a work in the twelfth century would not make any sense, as by that time the pagan followers of Proclus were all virtually gone. On this basis, for instance, even Amato, while accepting the hypothesis that Nicholas re-elaborated on an earlier Procopian work, concludes that Nicholas' work is a merely rhetorical one insofar as there were no real opponents, i.e. no real followers of Proclus, at the time. ${ }^{56}$ We disagree with this view and we believe that Procopius scholars from Dräseke to Amato have underestimated the historical circumstances surrounding the circulation of Proclus' work in the twelfth century. These suggest that far from being a merely rhetorical work with no real target, the Refutatio Procli (be it entirely the work of Nicholas or a reelaboration of an earlier Procopian work) fits in well with the twelfth-century Byzantine intellectual history. In what follows we shall summarize the evidence. ${ }^{57}$

In the eleventh century Michael Psellos celebrated Proclus as the best among Greek philosophers ${ }^{58}$ and devoted much attention to the Elements of Theology. ${ }^{99}$ Psellos' pupil, John Italos, discussed at length Elements of Theology 69,

\footnotetext{
55 Nicholas of Methone, Refutation of Proclus' Elements of Theology, p. 71.10-14.

56 Cf. supra p. 98.

57 On this topic see Podskalsky 1976 and Angelou 1984, p. LIII-LXIV. See also Robinson's paper in this volume.

58 Reinsch 2014, p. 6.38.3-5.

59 Michael Psellos, Opuscula, v. 1, 7, p. 29.45-46, Theologica, 11, p. 43.21-24. On this subject see O'Meara 2014.
} 
where Proclus expounds his whole-and-parts theory, ${ }^{60}$ while in the first half of the twelfth century Eustratios of Nicaea excerpted from this and other Proclean works as well. Possibly around the same period Ioane Petritsi translated the Elements of Theology into Georgian and wrote a commentary on it. ${ }^{61}$

Nonetheless, Proclus' most passionate readers already admitted that he (and the other Neoplatonists) were often incompatible with Christian dogma. ${ }^{62}$ In one of his meteorological treatises Michael Psellos writes, with regard to the demonology of the Chaldean Oracles, that Proclus is just a "story-teller" or "charlatan" ( $\dot{0} \tau \varepsilon p \alpha \tau 0 \lambda o^{\prime} \gamma \varsigma$ ), ${ }^{63}$ i.e. someone who tells absurd stories, while the Chaldean Oracles themselves are said to be "foolish talks" ( $\lambda \eta p \omega \delta i \alpha l),{ }^{64}$ an expression which among Church Fathers was used with respect to heresies. ${ }^{65} \mathrm{In}$ the same vein, after summarizing the Hellenic view on the evocation of deities, Psellos comments: "These were the absurd teachings of Porphyry, Iamblichus and Proclus the story-teller. We wish to make it clear that none of these teachings is a true one, but we have to learn not only to discern the therapeutic herbs, but also the poisonous ones, in order to become healthy with the former and to avoid the latter, without embracing extraneous doctrines as if they were ours".66

There are several similar later statements. George Tornikès' Funeral Oration on princess Anna Komnene is one of the best examples. In this text, written only a few years earlier than Nicholas' Refutatio Procli, ${ }^{67}$ Tornikès adopts the very same strategy as Psellos: he lists philosophers and associates them with doctrines which cannot be reconciled with the orthodoxy accepted at the time. In this way the author suggests that Anna's fondness for philosophy was a pious one. The first to appear is Aristotle, whom Tornikès blames for his theory on the eternity of the world and the denial of the Creator and divine providence. ${ }^{68}$

\footnotetext{
6o John Italos, Quaestiones Quodlibetales, p. 15.

61 On this Günther 2007, p. 1-25. See also Alexidze 2014.

62 Cf. e.g. Michael Psellos, Opuscula, 19, p. 89.28-33.

63 The word bears a strong negative meaning. Cf. A Patristic Greek Lexicon, ad loc.

64 Michael Psellos, Philosophica Minora, op. 19, p. 74,167-179. Michael Italos, Lettres et discours, p. 113.17-20.

65 See $A$ Patristic Greek Lexicon, ad loc.

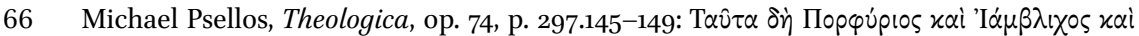

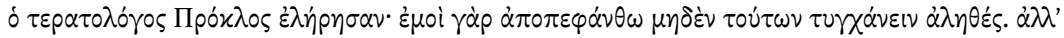

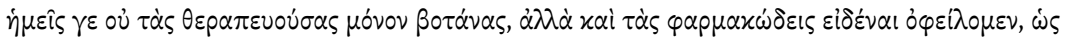

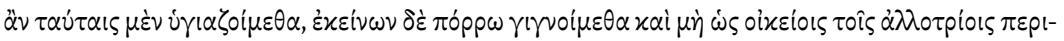
$\pi i \pi \tau o \mu \varepsilon v$. Michael Psellos, Theologica, op. 9o, p. 354.52-56. Other similar texts by Psellos are discussed in Maltese 1996.

67 See Angelou 1984, p. XLII-XLIII.

68 George Tornikès, A Funeral Oration, p. 285.14-16. On this allegation, see Bydén 2013, p. 159162 and p. 164-165.
} 
Then comes Plato, who is praised for his acceptance of a Demiurge, creator of the Universe, but whose doctrine of separate ideas is rejected as impious. ${ }^{69} \mathrm{On}$ the human soul, according to Tornikès, Anna stands more with the Platonists in order to avoid the traditional prejudice on the perishability of Aristotle's soul. Yet Tornikès adds that she rejected the Platonic metempsychosis and accepted the more nuanced understanding of Aristotle's psychology as elaborated by earlier commentators that sees only the lower faculties as perishable, whereas the intellect is eternal and immortal. ${ }^{70} \mathrm{~A}$ bit later in the text, the Neoplatonists Proclus and Iamblichus are mentioned in opposition to Ps.-Dionysius the Areopagite and his alleged master Hierotheos. ${ }^{71}$ Having said that princess Anna followed the latter two, rather than the former two, Tornikès suggests that Anna's education, although comprehensive, was animated by the awareness of the limits of ancient philosophy. In this respect Tornikès depicts the figure of the ideal intellectual of the time as someone who mixes intellectual curiosity with an awareness of the limits and realm of validity of the earlier philosophical tradition.

69 George Tornikès, A Funeral Oration, p. 287.12-15.

70 George Tornikès, A Funeral Oration, p. 289.3-19. The Byzantine inherited from the earlier Patristic literature and from the earlier philosophical authority of Atticus (see Atticus, Fragments, fr. 7bis) the prejudice that saw Aristotle's theory on the soul as purporting its corruption once the body ceases to exist. Some of these witnesses are collected in Bydén 2013, p. 163-164. However, the solution developed in Late Antiquity, according to which only the intellect survives the corruption of the body was equally known in Byzantium. This is what Tornikès refers to when he mentions the notion of "double entelecheia" (cf. George Tornikès, A Funeral Oration, p. 289.17) as that which allows him to accept Aristotle's psychology. A very similar textual parallel is found in Priscianus Lydus' commentary on

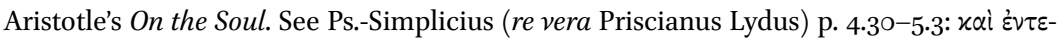

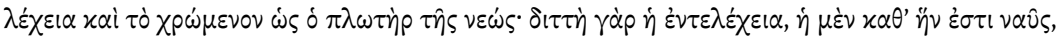

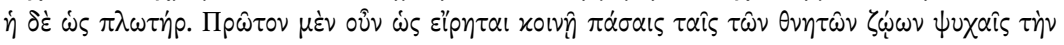

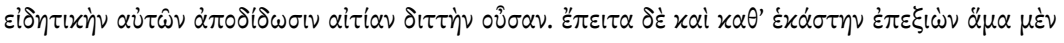

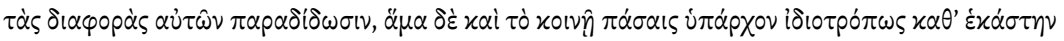

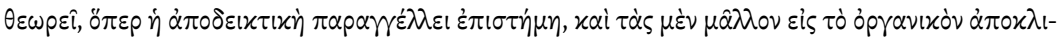

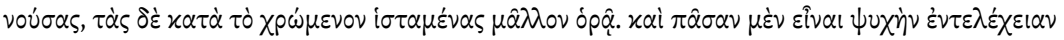

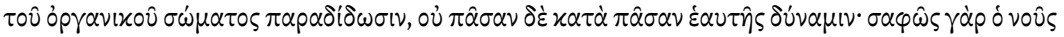

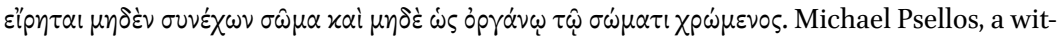
ness closer to Tornikès who knew Ps.-Simplicius' commentary (according to Steel 2003, p. 28), refers to the notion of "double entelecheia" as well. Cf. Michael Psellos, Opuscula, 13, p. 44.22-25. As the editor of Psellos' text diligently noted, the whole text is made out of excerpts from Philoponus' commentary on Aristotle's On the Soul. The most relevant Byzantine witnesses that agree with the commentators on this point have been collected in Bydén 2013, p. 174, n. 74. 
The same strategy had been adopted in Anna's Alexiad, written not so many years before the Refutatio Procli. While reconstructing the events that led to the condemnation of John Italos, ${ }^{72}$ Anna depicts Italos as a reader of Proclus, Plato, Porphyry and Iamblichus, on the one hand, and of Aristotle's logic, on the other, who had no awareness of the value of the Neoplatonic doctrines and their limits. Thus, just as Tornikès depicted Anna's pious approach to philosophy by opposing Proclus and Iamblichus to Ps.-Dionysius the Areopagite and Hierotheos, Anna compares Italos' undiscerning approach to the pious attitude of her parents towards philosophical literature. In particular Anna's intermezzo on her parents opposes the books by Proclus, Iamblichus and the like to those by the Church Fathers, in particular Maximus the Confessor, whose writings Anna's mother always brought with her, even to breakfast. In Anna's narrative this opposition exemplifies the difference between true Wisdom and the wisdom of this world. ${ }^{73}$

However, Tornikès' and Anna's rhetoric should not be understood as fictional. Their statements actually reflect the way the philosophy of the Neoplatonists (and that of Aristotle's non-logical works as well) was taught even by those who, like Psellos, were passionate readers of Neoplatonic books. In fact, as we have seen before, this does not prevent Psellos from accusing Porphyry and Iamblichus of talking non-sense with regard to their account of the causation process. In this very same passage, which in many respects resembles that discussed at the beginning of this chapter, Proclus is questionned for his "fairy tales" ( $\tau \varepsilon \rho \alpha \tau 0 \lambda \circ \gamma$ ial) on the same subject. Psellos' words could not have been clearer: "let us dismiss Proclus' fairy tales on the way things come to be in the world", ${ }^{74}$ i.e. through intermediary causes, something which in Psellos' view compromises the Christian prerogatives of the First Cause as the only Cause of the Universe. This critical approach to Proclus anticipates Nicholas' Refutatio Procli, where Nicholas criticizes Proclus on this and other topics as well. In this respect, one cannot help but notice that the Refutatio Procli fits in very well with the twelfth-century Byzantine intellectual history.

In the previous sections of this paper we demonstrated that Nicholas' Refutatio Procli (including the supposedly Procopian fragments) conveys the author's

72 On Italos' condemnation see Clucas 1981, to be updated and corrected with Gouillard 1985.

73 Anna Komnene, Alexias, p. 5.9.1-3.

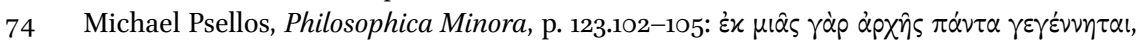

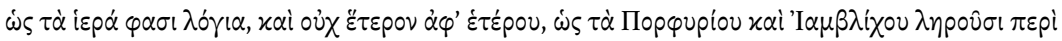

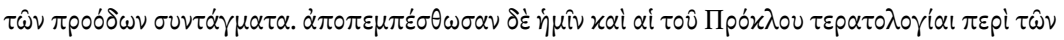
$\dot{\alpha} \pi \circ \gamma \varepsilon \nu \nu \eta \dot{\sigma \varepsilon \omega \nu}[\ldots]$. 
concerns for contemporary theological issues such as the Filioque. ${ }^{75}$ There is more. Three times in the Refutatio Procli Nicholas cautiously accepts Proclus' theory that the effects revert upon the causes, but warns the reader not to understand this in terms of Origen's apokatastasis. ${ }^{76}$ The author here suggests that Origen derived his apokatastasis theory from Proclus. Such a statement would be rather bizarre if the author were Procopius of Gaza, who would surely have known that this was chronologically impossible. However, it fits well with Nicholas' theological endeavours. In fact, Nicholas wrote a theological treatise on I Cor. 15.28 in order to dissuade contemporary readers of this text from understanding the sentence iv $\nu \hat{\eta} \hat{\delta} \Theta \varepsilon \dot{\zeta} \varsigma \tau \dot{\alpha} \pi \dot{\alpha} \nu \tau \alpha \dot{\varepsilon} \nu \pi \hat{\alpha} \sigma \mathrm{l}$ as a reference to Origen's apokatastasis. ${ }^{77}$ The interesting thing is that the expression $\tau \dot{\alpha} \pi \dot{\alpha} \nu \tau \alpha \dot{\varepsilon} \nu$ $\pi \hat{\alpha} \sigma \mathrm{l}$ occurs in prop. 103 of Proclus' Elements of Theology as well, where Proclus writes: "All things are in all things, but in each according to its proper nature"

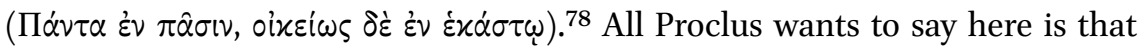
participation takes place according to the status of the participant. Nicholas' comments on this text make it clear that all things are in God insofar as $\mathrm{He}$ is their cause and that God is in all things according to participation, but not according to existence, for, if so, each thing would be indistinguishable from the others. ${ }^{79}$ Doubtless Nicholas must have connected these texts in that they are both part of one and the same concern, namely avoiding confusion between Cause and effects, Creator and creatures.

From this it is pretty clear that the Refutatio Procli reflects theological concerns discussed by Nicholas elsewhere. This is even more evident when one compares the Refutatio Procli with Nicholas' efforts in the controversy over the liturgical expression "For you are the Offerer, the Offered, the One who receives"

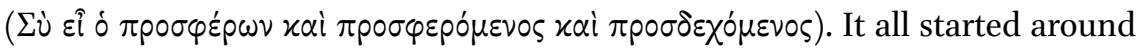
1155, when Nikephoros Basilakes and Michael of Thessaloniki, two teachers in the Patriarchal School of Constantinople, suggested that the rendering of Christ simultaneously as victim, officiant and receiver is self-contradictory. ${ }^{80}$ By contrast, according to these teachers, the sacrifice was offered to the Father alone. Nikephoros and Michael were condemned in 1156, but found a power ally in the patriarch-elect of Antioch, Soterichos Panteugenes. The latter is probably

\footnotetext{
75 Cf. supra p. 103-107.

76 Nicholas of Methone, Refutation of Proclus' Elements of Theology, p. 41.12-14; 42.13-15; 149.27-28.

77 Cf. Angelou 1984, p. LXIII.

78 Proclus, The Elements of Theology, prop. 103, p. 92.13-16.

79 Nicholas of Methone, Refutation of Proclus' Elements of Theology, 103, p. 99.30-32.

8o See Kazdhan, Epstein 1985, p. 16o-161; Magdalino 1993, p. 279-289; Felmy 2011.
} 
to be identified with the Soterichos who was author of a work on the eternal generation of the Son addressed to Patriarch Michael II Oxeites (Korkouas) (1143-1146) in MS Angel.gr. 43, f. 189v-192.

Soterichos is an interesting figure in the reception of Plato and Platonism in twelfth-century Byzantium. In order to support his view on the nature of Christ's sacrifice he composed a Platonic dialogue; ${ }^{81}$ when questioned by the synod, he answered with an apology whose words echo here and there the vocabulary of Plato's Apology of Socrates..$^{82}$ More importantly, Soterichos may be the author of a certain number of scholia to Nicomachus' Introduction to Arithmetic largely taken from Proclus' commentary on the Timaeus. ${ }^{83}$

Both because of his view on this theological controversy and because of his fondness for Platonism, Soterichos exemplified everything Nicholas disliked. In fact, he was personally involved in the controversy over Christ's sacrifice and challenged Soterichos's teaching in a work known as Refutation of the

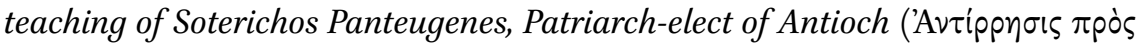

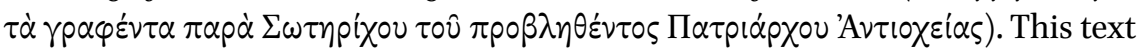
is important for two reasons: first, its existence demonstrates that Nicholas was accustomed to composing works in the form of a refutation; second, it is important because, just as in the case of his opposition to the Filioque and in that of the right interpretation of I Cor. 15.28, Nicholas here saw the controversy with Soterichos through the lens of his opposition to Proclus' Neoplatonism. Let us give an example of this.

Following Aristotle's Posterior Analytics 1.22 (83a33), section 184 of Nicholas' Refutatio Procli dismisses in toto Proclus' classes of divine soul and Gods as "twittering" ( $\tau \varepsilon p \varepsilon \tau i \sigma \mu \alpha \tau \alpha)$. Just as Aristotle had rejected Plato's theory of forms insofar as this treats concepts as self-subsisting realities, so the Christian Nicholas challenges Proclus' classes of gods and divine souls as mere notions with no existence beyond the mind that conceives them. ${ }^{84}$ Unsurprisingly, this very same text parallels Nicholas' Refutatio ('Avtippnoıs) of Soterichos. According to Nicholas, while defending the view that the sacrifice is offered to the Father alone, Soterichos had denied the very status of the Trinity and had considered the Father and the Son as two distinct and independent substances. According to Nicholas, Soterichos does away with the notion of person and relies exclusively on that of nature. But this would be absurd, for-claims Nicholas-not

\footnotetext{
$81 \quad$ See Spingou 2017.

82 See Trizio 2019, p. 596-597.

83 Part of the tradition of the scholia ascribes them to Michael Psellos. See Moore 2005, PHI 72a e PHI 72b. See Hofstetter 2018.

84 Nicholas of Methone, Refutation of Proclus' Elements of Theology, p. 184, 160.18-23.
} 
even Plato introduced forms or ideas as self-subsisting entities or natures. ${ }^{85}$ Intriguingly, Nicholas attributes to Plato a theory according to which genus and species, understood as ideas, can be more or less general and are called "henads". Obviously here Nicholas attributes a well-known Proclean doctrine to Plato. ${ }^{86}$ By the same token, when Nicholas refers to Plato's distinction among primary and secondary deities he alludes to Proclus' classifications of souls and deities. ${ }^{87}$ Just as he did in the Refutatio Procli, in his Refutatio Soterichi, Nicholas mentions Aristotle's description of the Platonic ideas as "twittering" ( $\tau \varepsilon \rho \varepsilon \tau i-$ $\sigma \mu \alpha \tau \alpha){ }^{88}$

From what has been said, it seems that Nicholas' Refutatio Procli conveys the main theological controversies of the time as if these could be traced back to one and the same source: Proclus. In other words, it seems that in Nicholas' view the most important theological controversies of his time (the Filioque, the interpretation of I Cor. 15.28, the dispute over Christ's sacrifice) could all be addressed through the prism of Proclus' Elements of Theology. In the end that is what Nicholas himself suggests in the prologue of the Refutatio Procli, where he explicitly intends to prevent those Christian readers of Proclus from slipping into blasphemous heresies. ${ }^{89}$ We believe that these included Nicholas' opponents in the theological controversies in which he was involved as a theologian.

Another Incongruence: The Use of Aristotle in the Refutatio Procli

Another feauture of the Refutatio Procli transmitted as Nicholas' is the distinctive Aristotelianism of its author. Nicholas exploits Ps.-Dionysius the Areopagite in order to contest Proclus' errors in theology, but when attacking Proclus for his philosophical mistakes, Nicholas makes use of Aristotle's physical theories as corrective of Proclus' errors. ${ }^{90}$ Section 96, for instance, challenges Proclus' theorem that "the power of every finite body, if it is infinite, is incorporeal." 11

85 Bibliotheca ecclesiastica, p. 324.9-27. Text discussed also in Golitsis 2014, p. 48 in connection to the scholia to Aristotle's Metaphysics in Ms Par.gr. 1853.

86 On which see Chlup 2012, p. 212-219.

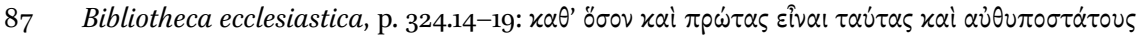

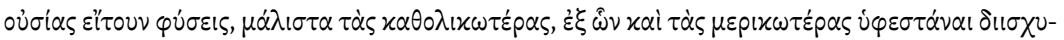

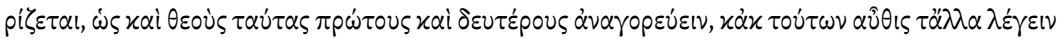
ن $\varphi$ i $\sigma \tau \sigma \sigma \theta \alpha \mathrm{l}$. See Chlup 2012, p. 119-127.

88 Bibliotheca ecclesiastica, p. 324.19-23.

89 Nicholas of Methone, Refutation of Proclus' Elements of Theology, p. 2.6-12.

9o See Trizio 2014, p. 207.

91 Proclus, The Elements of Theology, prop. 96. 
Nicholas here rejects as superfluous Proclus' restriction of the principle at hand to finite bodies alone on the basis that, as Aristotle states in Physics $3.5 .205^{\mathrm{b}} 35^{-}$ 206a7, there is no such thing as an infinite body. ${ }^{92}$ Accordingly, in section 94 of the Refutatio Procli, Nicholas criticises Proclus' theorem that "all perpetuity is a certain infinity, but not every infinity is perpetuity" by recalling that according to Aristotle's On the Heavens 1.5-9 there is only one world and this cannot be infinite in nature. ${ }^{93}$

By contrast, as Michael W. Champion has elucidated, along with the refusal of other philosophical sources, Procopius of Gaza's known work endorses a rather negative attitude towards Aristotle's physics and cosmology. For example, in his Commentary on Genesis Procopius elaborates a powerful rejection of the cornerstones of Aristotle's physical theory, such as Aristotle's prime matter (cf. e.g. Metaphysics 7.3.1028b36-1029a2o; Physics, 4.2.209b6-11), as something that has no quality, dimension or form. ${ }^{94}$ In the same work, Procopius dismisses the Aristotelian arguments on the eternity of matter (In de caelo 3.2.301b30-302a9; Physics 1.9.192a27-32) and restores the Christian view on this subject. ${ }^{95}$ It is surely true that in all these cases Procopius contests Aristotle as one of the several Greek philosophers supporting unacceptable views on creation, but still the difference in the treatment of Aristotle in the Commentary on Genesis and in the Refutatio Procli is so striking that it is hard, if not impossible, to believe that these works belong to one and the same author. Nor does the positive use of Aristotle found in the Refutatio Procli correspond with other late-antique works similar to the Commentary on Genesis, such as, for instance, Ps.-Justin's Confutatio quorundam Aristotelis dogmatum, a work possibly coming from the milieu of Gaza. ${ }^{96}$

On the contrary, the acceptance of Aristotle in the Refutatio Procli resembles the wider twelfth-century reception of Aristotle as a safe authority compatible with Christianity vis-à-vis the more dangerous Platonic source-material. Two witnesses from this period are relevant. The first witness is the inaugural lecture given around the mid-twelfth century by Michael III 'Anchialos' on the occasion of his appointment as consul of the philosophers. Here Michael promises to stick to the safer Aristotelian logic and meteorology and to avoid the more dangerous Platonic doctrines. ${ }^{97}$ The second witness comes from a set

\footnotetext{
92 Nicholas of Methone, Refutation of Proclus' Elements of Theology, 96, p. 94.22-24.

93 Nicholas of Methone, Refutation of Proclus' Elements of Theology, 94, p. 93.12-13.

94 Procopius of Gaza, Commentary on Genesis, p. 5.111-10.25o. Cf. Champion 2014, p. 112-113.

95 Procopius of Gaza, Commentary on Genesis, p. 5.111-10.25o. Cf. Champion 2014, p. 114.

96 Cf. Boeri 2009.

97 Browning 1961, p. 190.103-110. On the dating of the text, see Polemis 2011.
} 
of twelfth-century scholia preserved in MS Par.gr. 1853 (f. 225v-308r). Here an anomyous scholiast wrote in the margin of Aristotle's Metaphysics his own personal remarks, which were mostly sympathetic towards Aristotle's philosophy and rather critical of Plato. As Pantelis Golitsis elucidates, there are strong philological similarities between the vocabulary of the scholia and Nicholas of Methone's distinctive antiplatonism. ${ }^{98}$

Clearly the positive appraisal of Aristotle's philosophy in the Refutatio Procli exemplifies twelfth-century intellectual trends. One can indeed contend that the passages of the Refutatio Procli where Nicholas sympathizes with Aristotle belong to Nicholas' alleged re-elaboration of an earlier version of the text by Procopius. And, yet, this positive usage of Aristotle only adds substance to the enormous pile of arguments favoring Nicholas' authorship of the text, which is so large that at a certain point one gets the impression that Nicholas had no need of an earlier version of the Refutatio and that nowhere in the text does the presence of an earlier version by Procopius appear evident at all.

We have already lengthily discussed the content and historical circumstances of the fragments of the Refutatio Procli found in the Vatican manuscripts. Let us now present the fragments from a philological point of view.

There are two fragments of the Refutatio Procli attributed to Procopius. They have both been copied in Mss Vat. gr. 1096 and Vat. gr. 604 by one and the same book-hand, that of the prolific Byzantine scribe and scholar Isaak Argyros. In particular chapter 146 of the Refutatio is found in Ms Vat. gr. 1096 at f. $5^{2 r_{12}}$ $5^{2 \mathrm{~V}_{18}}$ and at f. 61r of the same manuscript. As to chapter 139, it is found in MS

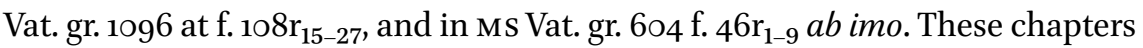
of the Refutatio Procli have been edited as authentic Procopian fragments by Amato (ch. 139 = fr. VIII.1; ch. 146 = fr. VIII.2), ${ }^{99}$ who concluded on this basis that the Refutatio Procli was originally composed by Procopius of Gaza and later reelaborated by Nicholas of Methone in the twelfth century. According to this view, the fragments in Mss Vat. gr. 1096 and Vat. gr. 604 are the only existing witnesses to the Procopian Refutatio Procli.

However, in its present state the Refutatio includes numerous features inconsistent with Procopius. ${ }^{100}$ In this regard, if we were to retain Amato's view,

\footnotetext{
98 Golitsis 2014, p. 43-5o.

99 Cf. supra p. 95-97.

100 Cf. supra p. 102-116.
} 
we must accept a paradox: the Refutatio is a twelfth-century work in all its parts with the exception of chapters 139 and 146, where the text is entirely Procopian. ${ }^{101}$ As said above, this conclusion invites more problems than it solves. Let us now add a few remarks concerning the textual aspects of the fragments of the Refutatio Procli attributed to Procopius in the Vaticani manuscripts. The first observation concerns the state of the fragments in the Vatican manuscripts, in particular the fact that they have all been copied by a single scribe. Amato's view on the origin of the fragments would be more compelling had the fragments been copied by two or more scribes independently from each other. However, this is not the case, for the scribe in our case is one and the same. It is pretty obvious that, being convinced of the Procopian authorship of the fragments, the scribe reproduced the same attribution whenever he copied the two texts. But Amato believes he can avoid this inconvenience on the basis of the state of the fragments in the manuscripts. In fact, the text of the fragments has been copied more than once in the Vaticani manuscripts, and the different redactions occasionally show some variant readings. From this Amato concludes that the scribe had at his disposal two different redactions both attributing the text (evidently independently from each other) to Procopius. ${ }^{102}$

This argument, however, becomes less compelling once we take into account the modus operandi of the scribe, who is known for introducing his own corrections in scribendo. ${ }^{103}$ Thus the variant readings present in the different redactions of the fragments may not indicate the existence of more than one tradition of the same text. More importantly, a close inspection of Amato's extensive list of variant readings, ${ }^{104}$ suggests that many are mere misreadings by the editor. ${ }^{105}$ For example, it is not true that chapter 139 as transmitted in Ms Vat. gr. 604 at $\mathrm{f} .46 \mathrm{r}$ does not read $x \alpha i$ before $\lambda \varepsilon^{\prime} \gamma o i \tau o$. The $x \alpha i$ is perfectly read in the usual abbreviated form. Vat. gr. 604 f. 46r and Vat. gr. 1096 f. 108r reads xupló $\tau \alpha \tau \alpha$ instead of Amato's xupıó $\alpha \tau \tau o v .{ }^{106}$ Ms Vat. gr. 1096 f. $108 \mathrm{r}$ (and not Vat. gr. 604, as Amato believes) reads $\tau \hat{\omega} \nu \mu \eta \dot{~ x o เ v \omega \nu o u ́ v \tau \omega \nu ~ i n s t e a d ~ o f ~ A m a t o ' s ~} \tau \hat{\omega} \nu$

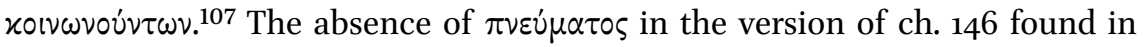

\footnotetext{
101 Cf. supra p. 98.

102 See Amato 2010, p. 12.

103 Cf. infra p. 124-128.

104 Cf. Amato 2010, p. 11-12.

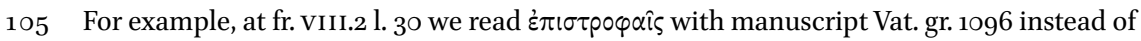
Amato's غ̇ं

106 The form $x$ vió $\tau \alpha \tau \alpha$ is found in some of the manuscripts of the Refutatio Procli edited as Nicholas of Methone.

107 In any case one must follow Ms Vat. gr. $604 \mathrm{f} .46 \mathrm{r}$ and the whole manuscript tradition of Nicholas of Methone's Refutatio Procli in reading $\tau \hat{\omega} v$ ovjpavíwv.
} 
MS Vat. gr. 1096 f. $5^{2 r-v}$ is a mere lapsus of the scribe. Ms Vat. gr. $1096 \mathrm{f} .5^{2 r}$ wrongly cites the fragment as $\rho \nu \varsigma^{\prime}$ instead of $\rho \mu \varsigma^{\prime}$, but Amato wrongly reads $\rho v^{\prime}$, just as he wrongly reads $\rho \mu^{\prime}$ instead of $\rho \mu \varsigma^{\prime}$ in the redaction of chapter 146 in Ms Vat. gr. 1096 at f. $61 r^{108}$ In the same manuscript, at f. 108r, we read ov่ $\delta \dot{v} v$

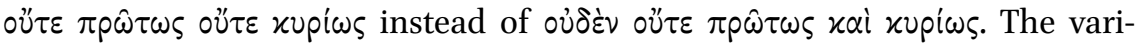

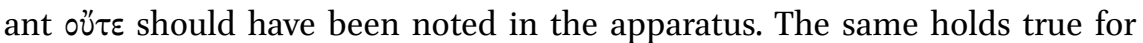
fr. ViII.2, l. 35, where Ms Vat. gr. $1096 \mathrm{f}$. $5^{2 \mathrm{~V}}$ does not read $x \alpha i$ and fr. VIII.2 1. 37, where Ms Vat. gr. 1006 f. 61r does not read $\varkappa \alpha i$ after $\varkappa \alpha \theta \dot{\alpha}$. Finally, Amato diligently noted the differences in the titles of the fragments in the Vaticani manuscripts, but did not realize that these are due to the fact that in Mss Vat. gr. $604 \mathrm{f}$. $46 \mathrm{r}$ and Vat. gr. $1096 \mathrm{f}$. $5^{2 \mathrm{r}-\mathrm{v}}$ and $61 \mathrm{r}$ the fragments are parts of an anthology prepared by the scribe for the composition of future works, whereas in Ms Vat. gr. 1096 f. 108r the fragments appear as a citation in a theological work.

In light of our analysis of the text, we believe that neither the number of the variant readings nor their type signifies the existence of more than one tradition or redaction of the fragments. The few discrepancies are mere corrections in scribendo or variants found in the manuscripts of Nicholas' Refutatio Procli, and, therefore, their importance should not be overstated.

The Fragments: A Paleographer's View. The Anti-Palamite florilegia of Vat. gr. 1096 and the Two Extracts of Nicholas of Methone's Refutatio Procli

MS Vat. gr. 1096 is a composite volume consisting of 246 folios, plus an independent unit between folios 170 and 171 which formerly belonged to the earlier Vat. gr. ${ }^{1892 .}{ }^{109}$ The manuscript contains seven codicological units which, with the exception of the last one (dating to the fifteenth century), are all linked to the activity of the Byzantine anti-Palamite circle close to the Kydones' brothers and Nikephoros' Gregoras' pupil Isaak Argyros. ${ }^{110}$ The latter is a key figure in both the so-called "Palaiologan Renaissance" of the late fourteenthcentury and in the theological controversies of the same period. In fact, Isaak shared the scientific interests of his master as well as his commitment to

\footnotetext{
108 The mistake has been corrected in the Teubner edition of the fragments.

109 On this unit see Mercati 1931, p. 23o. For a description of the codex see also Polemis 2012, p. LXX-LXXX.

110 Cf. Rigo 1989.
} 
refute the theological teachings of Gregory Palamas. Before clarifying the role played by Argyros in this codex, especially in regard to the two fragments from Nicholas of Methone's Refutatio Procli attributed to Procopius, we consider it worthwhile to offer a preliminary description of the units' content.

The first unit (f. 1-64) gathers numerous extracts from different Church Fathers, copied by at least eight different hands. Among these it is possible to distinguish one main scribe, $\mathrm{A}$, to whom we can ascribe the entire copy of the collection of texts transmitted at f. $17 \mathrm{r}-58 \mathrm{v}$. Although anonymous, this scribe is otherwise known from several other manuscripts linked to Isaak Argyros' anti-Palamite circle. The hand of this scribe is quite regular, proceeds with geometrically-shaped letters and angular strokes giving an aspect both stiff and forced. This is especially true for his formal handwriting, where he forgoes cursive in favor of sharp right angles. Typical of this scribe's handwriting are the shape of uppercase beta, lowercase epsilon in an ancient form (cut in half) and phi written with oval loop. Among ligatures the most characteristic is that of tau-iota, with the vowel lifting from the basic line and surmounted by dieresis. ${ }^{111}$

Afterwards, other hands added further implementations wherever they found empty spaces, such as blank pages, marginal vacua or half-empty sheets. These bookhands include Isaak Argyros, who contributed to the composition of this theological anthology, transcribing twice chapter 146 from Nicholas' Refutatio Procli. Isaak copied this text first at f. $5^{2 \mathrm{r}-52 \mathrm{v}}$; then he copied it again at f. 6ri. In both cases Argyros registered the title of the work from which he drew the fragments. Yet, he made a mistake at $\mathrm{f}$. $5^{2 \mathrm{r}}$ as he reported the text as chapter 156 , instead of chapter 146 . At f. 52 r we read: Прохо

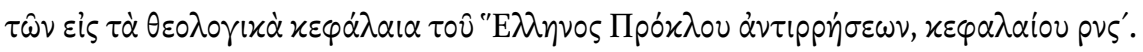
Instead at $\mathrm{f}$. 61r the same chapter, equally considered as stemming from Pro-

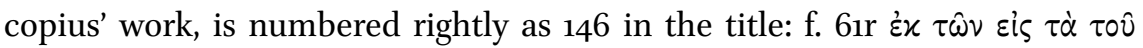

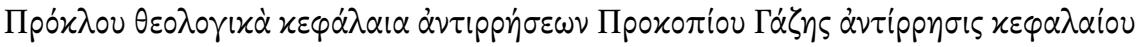
pus.112

The identification of Isaak Argyros' hand is due to Mercati, who in 1931 identified this book-hand in several Vatican manuscripts related to the Palamite

\footnotetext{
111 In Gioffreda 2020 the copyist here named as A has been recognized in the following manuscripts, all of which related to anti-Palamite circle: Laur. Plut. 56.14 (f. 1-163v); Vat. gr. 604 (f. 17r-47); Vat. gr. 678 (f. 63r-69v); Vat. gr. 1094 (f. 63v); Vat. gr. 1096 (f. 1r-8r, 9r-17v, 19r-2or, 21rv, 22v-23r, 26r-27r, 36v-4or, 53r-54v, 64r-64v). For a specimen see: https://digi. vatlib.it/view/MSS_Vat.gr.1og6.

112 Cf. Mercati 1931, p. 265-266 and Bianconi 2008, p. 354.
} 
controversy, ${ }^{113}$ including the above-mentioned fragments as well as another fragment of the Refutatio Procli in Ms Vat. gr. 604 (f. 39-47). ${ }^{114}$

As it is well known to specialists, Mercati has gained a definitive confirmation for his hypothetical identification thanks to a marginal note left by Argyros on f. $138 \mathrm{v}$ of Vat. gr. 176 , a witness of Ptolemy's Harmonica. ${ }^{115}$ The numerous scholia surrounding the main text in this manuscript must be assigned to Argyros' hand as well. ${ }^{116}$ Argyros's note reads as follows: "This material has been revised not by the philosopher Gregoras, but rather by his pupil, the monk

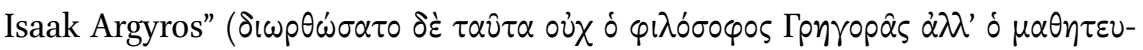

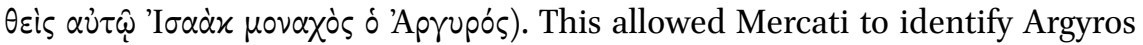
as the main scribe of the codex and as the author of several of its exegetical notes.

Let us present in short the characteristics of Argyros' book-hand.

\subsection{Argyros' Hand}

Argyros' handwriting is a small, regular and tidy hand, which slightly bends to the right, and is marked by the presence of angular strokes and vertical traits stretched over both the upper and lower writing lines. ${ }^{117}$ In spite of its several abbreviations and tachygraph signs, Argyros' cursive handwriting still remains stylish and neat. In light of these features and because of the angular strokes peculiar to this handwriting, Argyros' book-hand has been associated with a

113 More recently after Mercati, who recognized Argyros' hand in Vat. gr. 6o4, Vat. gr. 1096, Vat. gr. 1102, Vat. gr. 1115, Vat. gr. 2335, other scholars have increased the attribution of Argyros in up to thirty manucripts. We indicate here for each attribution the scholars in brackets: Laur. Plut. 28.13 (Mondrain 2008), Laur. Plut. 89 sup. 48 (Bianconi 2008); Marc. gr. 155 (Bianconi 2008, Mondrain 2008), Marc. gr. 162 (Mondrain 2008), Marc. gr. 308 (Bianconi 2008, Mondrain 2008), Marc. gr. 310 (Bianconi 2008), Marc. gr. 323 (Bianconi 2008, Mondrain 2008); Neap. III D 37 (Bianconi 2008), Norimb. Cent. v App. 36, Norimb. Cent. v App. 37, Norimb. Cent. v App. 38 (Mondrain 2008, Murr 1930); Par. gr. 940 (Mondrain 2008), Par. gr. 1246, Par. gr. 1276 (Mondrain 2008, Pérez Martín 2008), Par. gr. 2507 (Mondrain 2008), Par. gr. 2758 (Mondrain 2008), Par. gr. 2821 (Bianconi 2008, Mondrain 2008); Parm. 154 (Bianconi 2008, Mondrain 2008); Prah. Xxv. C. 31 (Mondrain 2008); Vat. Pal. gr. 174 (Menchelli 2014), Vat. gr. 81 (Bianconi 2008), Vat. gr. 1094 (Polemis 2012), Vat. gr. 1721 (Bianconi 2008). In addition, there are three new identifications, namely that of Esc. Y III 21, Vat. gr. 573 and Par. gr. 1672, for those see Gioffreda 2020.

114 See again Mercati 1931, p. 158-159, p. 259-265.

115 See Mercati 1931 and Laue, Makris 20o2, p. 226-245.

116 This conjectural identification by Düring 1930, p. XXxıII was confirmed by Mercati 1931, p. 229, n. 6.

117 For a description of Argyros' hand see Bianconi 2008, p. 356, Mondrain 2008, p. 165-170, Pérez Martín 2008, p. 445-448 and Gioffreda 2020, p. 29-43. 
current known as "geometrical". Interestingly, the book-hands belonging to this category are found in several fourteenth-century mathematical and scientific manuscripts. ${ }^{118}$

Furthermore, according to Bianconi and Pérez Martín, Argyros' script is based on two different models: on the one hand, the above-mentioned geometrical script; on the other, the individual writing of Argyros' teacher, Nikephoros Gregoras. ${ }^{119}$ Typical of the latter model are the shapes of the bilobular beta, rare in "geometrical" handwriting, of the enlarged uppercase kappa and the frequent ligatures of iota and tau, with the latter marked by an angular track at the bottom. The influence of Gregoras' script is more evident in Argyros' cursive handwriting which is mostly used for copying scholia, marginal notes or vacua spaces. It is, by contrast, rarely used for copying main texts. In the latter case Argyros adopts a more regular script typical of the so-called $\tau \hat{\omega} \nu$ 'O $\delta \eta \gamma \hat{\omega} \nu$ style, although in a version less formal than expected. Typical of this script is the zeta in form of two, with angular tracts, and the uppercases delta and lambda. Both these handwritings coexist for example in f. $177 \mathrm{r}$ of ms. Neap. III $D_{37}$.

\subsection{Argyros and the Refutatio Procli}

As stated by Mercati long ago, the two extracts of the Refutatio Procli in Vat. gr. 1096 have clearly been copied by Isaak Argyros. On the basis of this identification we can go one step further in the attempt to clarify the reasons why Argyros copied these two fragments, as well as the manner in which he used and re-elaborated them for his own purposes. Before doing so, we shall briefly present the other fragment from Nicholas' Refutatio found at f. 46r of Vat. gr. $604 .{ }^{120}$

This codex is also composite and collects at the beginning two different theological anthologies. Just as in the case of Ms Vat. gr. 1096, the two anthologies preserved in MS Vat. gr. 604 concern the fourteenth-century Palamite controversy. ${ }^{121}$ The first collects passages concerning the nature of the Taboric light (f. 17-38), whereas the second contains a theological florilegium against the essence-energies distinction (f. 39-47). Both anthologies are copied in their main parts by the main copyist of the anthology transmitted in the first unit

\footnotetext{
118 For a description of these handwriting see Pérez Martín 2008, p. 440.

119 Descriptions of Argyros' hand can be found in Bianconi 2008, Pérez Martín 2008 and Mondrain 2008 and Gioffreda 2020.

120 Mercati 1931, p. 158-159, p. 259-265. For a reproduction of the manuscript see: https://digi .vatlib.it/view/MSS_Vat.gr.6o4.

121 On this controversy, see Russell 2017.
} 
of Vat. gr. 1096, namely scribe A, who copied f. $17 \mathrm{r}-58 \mathrm{v}$ with exception of the five annotations left by Argyros on f. 46r-47r. ${ }^{122}$ Among these, we should focus on that one at f. 46r, l. 1-9, where Argyros transcribed chapter 139 of Nicholas' Refutatio under the name of Procopius of Gaza: $\varphi \eta \sigma i \quad \delta \dot{\varepsilon}$ xai o

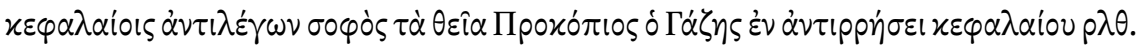

Before addressing the issue of the real motivation behind Argyros' exploitation of the Refutatio Procli, we shall briefly present other anthologies of the same kind copied under the same circumstance of those preserved in the two aforementioned Vatican manuscripts. In fact, we believe that Argyros' excerpting from the Refutatio Procli can only be understood when seen in the light of his commitment against the Palamite theology.

\subsubsection{Other Anti-Palamite Anthologies}

The production of dogmatic anthologies containing extracts from different works seems to be one of the most important prerogatives of the figures known for taking part in the Palamite controversy. These collections often occupy one or two units of a manuscript and gather extracts from the earlier synodal tomes, especially those of 1341 and 1351, passages from the Church Fathers and from later authors, and finally passages derived from the opponents' works. Sometimes they are found as organized in topics and introduced by pinakes that illustrate their content. In all likelihood the composition of these anthologies had several purposes, such as facilitating the research of crucial and useful quotations, making authoritative sources available to those who wished to write their own works, making available to authors an appropriate procedure for drafting of new texts and for producing new anthologies. In the Palamite controversy both sides resorted to such a literary product.

Thanks to Antonio Rigo's important studies we know of several of these theological anthologies composed by both pro-Palamite theologians and by their opponents. ${ }^{123}$ We have already mentioned those contained in Vatt. grr. 604 and 1096 copied, among others, by scribe A and by Isaak Argyros. Both textual and paleographical evidence allow us to relate to the same milieu the anthologies transmitted in the following manuscripts: Marc. gr. 162 (f. 1r-103v), Vat. gr. 678 (f. 62-103v) and Vall. F. 30 (f. 2r-297v).

Let us provide a few remarks on these anthologies, on the way they were produced and on their use by the theologians involved in the controversy.

122 Russell 2017, p. 264-265.

123 Rigo 1989, p. 135-149. 


\subsubsection{Ms Vat. gr. 678}

MS Vat. gr. 678 preserves at f. $62 \mathrm{r}-103 \mathrm{v}$ a florilegium consisting of various excerpts and divided into three sections: the first one (f. 62v-86v) is divided into twelve chapters and transmits among other texts the profession of faith of the Byzantine Thomist and anti-Palamite Prochoros Kydones; ${ }^{124}$ the second one (f. $87 \mathrm{r}-96 \mathrm{v}$ ) is composed of nine chapters; the last (f. $96 \mathrm{v}-103 \mathrm{v}$ ) preserves various extracts from Gregory Palamas' works under the title: Tov $\Pi \alpha \lambda \alpha \mu \hat{\alpha}$

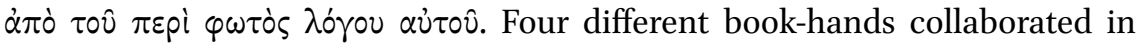
these folios. All of them are copyists involved in the production of several manuscripts belonging to Isaak Argyros' circle. ${ }^{25}$ For example, f. 63 r-69r have been copied by the previously-mentioned Scribe A, while Argyros left three autograph annotations on the much-debated episode of Christ's transfiguration on Mount Tabor (Mt. 17.1-8 et passim): ${ }^{126}$ an excerpt from Leontius of Byzantium's Homelia in Trasfigurationem on f. 86v, wrongly transmitted as John Chrysostom; two unknown passages at f. 103v on the light seen by the disciples on Mount Tabor; ${ }^{127}$ and finally, in the margins of f. 101v-102r, a passage from Anastasius Sinaita's Homelia in Trasfigurationem. ${ }^{128}$

\subsubsection{Ms Marc. gr. 162}

The first unit of this fourteenth-century manuscript transmits an anti-Palamite florilegium in 64 chapters (f. $1 \mathrm{r}-103 \mathrm{v}$ ) and Argyros' treatise De paternitate et filiatione dei $(104 \mathrm{r}-116 \mathrm{v})$, both copied by an anonymous but prolific scribe, whose career has been related to Nikephoros Gregoras and his circle. ${ }^{129}$ The second unit preserves one of John Kyparissiotes' work, Utrum proprietates personales in Trinitate ab essentia differant (f. $117 \mathrm{r}-125 \mathrm{v}$ ) copied by the hand of John Dukas Malakes. ${ }^{130}$ In the marginal spaces of this second unit Argyros left two different annotations, at f. $117 \mathrm{r}$ and $\mathrm{f} .118 \mathrm{v} .{ }^{131}$ In light of this we can safely assume that Argyros supervised the copy not only of this unit, but also of the first unit

\footnotetext{
124 On $P L P$, no. 13883.

125 On this manuscript Cf. Codices Vaticani Graeci III, p. 132-136, and Mercati 1931, p. 248-251, and Bianconi 2008, p. 362-365.

126 Among others, we detected the following book-hands: Anonymous $\xi$ at f. $62 \mathrm{r}, 69 \mathrm{v}-72 \mathrm{v}$,

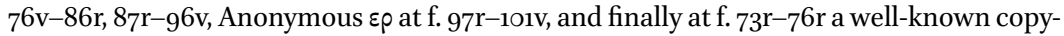
ist named John Dukas Malakes. On the latter, see Gioffreda 2020, p. 140-141.

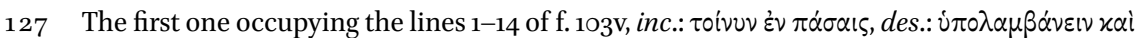

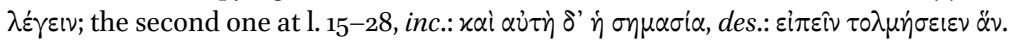

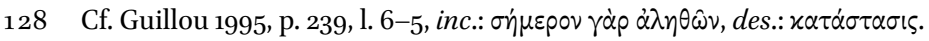

129 See Bianconi 2015, p. 261, n. 126, also for the bibliography.

130 Cf. Gioffreda 2020, p. 51, 62, 248. On Kyparissiotes cf. PLP 13900.

131 See Mondrain 2008, p. 168.
} 
containing the anti-Palamite florilegium, from which he derived excerpts from Isaac of Nineveh, Evagrius Ponticus and Diadocus of Photice. ${ }^{132}$

\subsubsection{Ms Vallicellianus $F$ 30}

Ms Vallicellianus F. 30 transmits at f. 2 r-297v a rich anti-palamite florilegium to be dated on the basis of a paleographical analysis to the fourteenth century, not to the fifteenth century as proposed by Martini's outdated catalogue of the Greek manuscripts preserved in Italy. ${ }^{133}$ The florilegium is divided into several chapters and has been mostly copied by two principal scribes, although later hands are present as well. The two main scribes display scholarly hands proper to the book-hands of this century.

This composition is based on the same Patristic and post-Patristic sources employed in the previous collections. It must be noted that in the margins of some of the fragments there are notes concerning the sources and books from which the passages were drawn. Among these, one of the scribes refers to the books of John Dukas Malakes. It is no coincidence that this name occurs also in the margins of Vat. gr. 604, where scribe A noted that the passage from Cyril of Alexandria on Luke's Gospel on the divine transfiguration (Luke 9.28-36) is

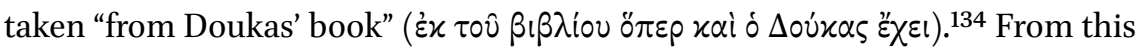
fact we can infer that in the milieu involved in the composition of anti-Palamite florilegia the same books circulated and that different copyists worked on the same source materials.

As Stiglmayr has shown, both florilegia in Ms Vat. gr. 1096 and in Ms Vallicellianus $\mathrm{F} 3 \mathrm{O}$ are very similar both with regard to their structure and content. ${ }^{135}$ Interestingly, in many instances Ms Vallicellianus $\mathrm{F} 3$ o transmits several scholia and excerpts with no indication of the authorship. ${ }^{136}$

\subsection{The Drafting of Argyros' Adversus Cantacuzenum}

The case of Isaak Argyros' Adversus Cantacuzenum (Argyros' work containing the excerpts from the Refutatio Procli ascribed to Procopius) offers a sample of the re-using of Patristic quotations by the individuals involved in the hesychast controversy. The work is addressed to John vi Kantakouzenos, a fervent defender of Gregory Palamas' teachings who served as Grand Domestikos

\footnotetext{
132 See Rigo 2012, p. 101-103.

133 See Martini 1902, p. 156-157.

134 On the annotations see Mercati 1931, p. 26o, 263-265, Rigo 1987-1989, p. 126-129 and Bianconi 2008, p. 364, n. 82.

135 Stiglmayr 1989, p. 263-301, 300-301.

136 Stiglmayr 1989, p. 30o-3o1.
} 
under emperor Andronikos III Palaiologos (1328-1341), as regent for John V Palaiologos (emperor from 1341) and as emperor between 1347-1354. ${ }^{137}$

We shall now provide some arguments that refute once and for all the attribution of the Adversus Cantacuzenum to Johannes Kyparissiotes, as suggested by the editor of the text, Ioannis Polemis, against the earlier views by Mercati and Rigo, who rightly attributed the text to Isaak Argyros. ${ }^{138}$ Mercati noticed that the Adversus Cantacuzenum contains several passages found in other treatises of the same Argyros. For example, in chapter 21, 1. 8-57 of Adversus Cantacuzenum (cfr. ed. Polemis 2012, p. 73-75) one can find the very same profession of faith written by Argyros in his letter addressed to Gedeon. ${ }^{139}$ Further textual concordances found by Mercati include the citations of the excerpts from Gregory of Nazianzus' Oratio XXIX and Oratio XIX found in Adversus Can-

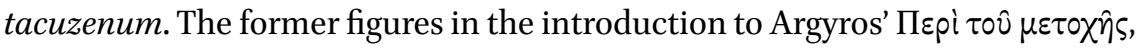
whereas both are found in the conclusion of Adversus Cantacuzenum. The latter was copied by Argyros at the beginning of Tomus Anthiochenus in Vat. gr. $2335^{140}$ and then employed at the very beginning of Adversus Cantacuzenum. ${ }^{141}$ In addition, Rigo proved the relationship between the Adversus Cantacuzenum and the anti-palamite florilegium contained in Marc. gr. 162, a manuscript that Argyros knew well, as demonstrated by the presence of his book-hands in this manuscript. Finally, Rigo pointed out that chapters 255-257 of Adversus Cantacuzenum include the same passages from Isaac of Nineveh, Evagrius Ponticus and Diadocus of Photice available on f. $55^{\mathrm{r}-} 57 \mathrm{v}$ of this anti-Palamite florilegium. ${ }^{142}$

Whereas the attribution of Adversus Cantacuzenus to Argyros appears certain beyond doubt, it is in our view important to describe the way Argyros re-elaborated and re-used the source-material available to him. In particular we would like to point out the strong connection between the previouslymentioned florilegia and Argyros' own works. For example, chapters 156-158 of Adversus Cantacuzenum are built around the extracts copied by Argyros at f. $46 \mathrm{r}-47 \mathrm{r}$ of the anthology transmitted in Vat. gr. 604. As mentioned above, at l. 6-8 of f. 46r Argyros copied the text of chapter 139 of the Refutatio Procli which he then used in chapter 158 of the Adversus Cantacuzenum, where it is

\footnotetext{
137 See $P L P 10973$.

138 Cf. Mercati 1931, p. 239-241, Polemis 2012, p. LIII-LXI and Rigo 2012, p. 100-103.

139 Cf. Candal 1957, p. 100.10-102.25.

140 About this Tomus see Mercati 1931, p. 209-218, 240-242 and Polemis 1993.

141 Cf. Mercati 1931, p. 231-242, 270-278, and Polemis 2012, p. 73-75.

142 Rigo 2012.
} 


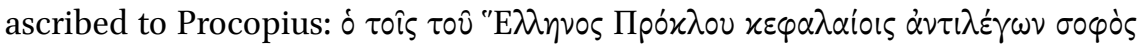

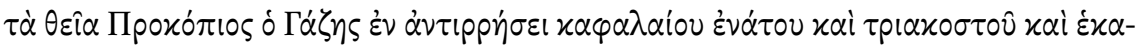
$\tau \circ \sigma \tau 0$. ${ }^{143}$

In other words, we believe that while investigating the cause for the wrong attribution to Procopius of chapters 139 and 146 of the Refutatio Procli, one must take into account the different authorial practices adopted by the scribe. Argyros first copied the excerpts from the Refutatio Procli in a florilegium which he prepared for the composition of his own works. He then reproduced the same text in a newly-composed work, in our case the Adversus Cantacuzenum. This neatly explains the variant readings in Ms Vat. gr. 1096 and in Vat. gr. 604. Whereas Amato thinks that these variants are witnesses to two traditions or redactions of the text, ${ }^{144}$ we are convinced that these few variant readings must be explained on the basis of Argyros' way of excerpting and copying the material. In fact, as shown extensively by Gioffreda, when copying a text Argyros was accustomed to add frequent corrections in scribendo. ${ }^{145}$ To modern scholars unfamiliar with Argyros' modus operandi, these corrections may be misunderstood as variant readings that hark back to other traditions or redactions of the text. However, research shows that in several manuscripts copied by Argyros this is not the case. The fragments copied in Mss Vat. gr. 1096 and Vat. gr. 604 could be among the many instances in which this tendency is more evident.

In other words, it is pretty clear that the chapters of the Refutatio Procli attributed to Procopius in MS Vat. gr. 1096 and Vat. gr. 604 have been copied according to different authorial practices. The extracts from the Refutatio Procli have been first copied as drafts for Argyros' private use and then they have been published in a theological work such as the Adversus Cantacuzenum. Like many of his contemporaries, Argyros first prepared a provisional draft and then an official published version of all source material. Accordingly, the various sources undergo a process of transformation from drafts into texts ready for publication. While selecting and publishing, the various excerpts are subject to revision, which explains the existence of a few variant readings between the different versions of the same text.

In sum, Argyros' excerpts from the Refutatio Procli attributed to Proclus as found in the aforementioned florilegia and in Argyros' theological pamphlet Adversus Cantacuzenum do not reflect two different traditions of the same text, but rather two different stages of the same editorial procedure: from the selection of the material to its final publication. In the same way the excerpts

\footnotetext{
143 Cf. ed. Polemis 2012, p. 191, cap. 158, l. 1-2.

144 Cf. Amato 2010, 12.

145 Gioffreda 2020, p. 90-95.
} 
copied by Argyros in another manuscript, Vat. gr. 678, were reused in his own writings. ${ }^{146}$ As Bianconi already noted, Argyros used the extract from Anastasius Sinaita's Homelia in Trasfigurationem, copied by himself in the margins of f. 101v-102r, in a short version of his Contra Dexium. ${ }^{147}$ This very same excerpt has been included by Argyros as chapter 38 of Adversus Cantacuzenum.

But what is the rationale behind Argyros' citations of patristic and postpatristic authorities in Adversus Cantacuzenum and in his other theological writings? As anticipated above, Argyros was a fervent anti-Palamite and a fierce opponent of the very core of the Palamite theology, namely the distinction between God's essence and his providential energies through which the divine economy is displayed. ${ }^{148}$ Understandably, in selecting his sources he favored those theological passages which in his view stressed God's substantial unity. This is precisely what he did when excerpting chapters 139 and 146 of the Refutatio Procli. A close inspection of these passages shows that both emphasizefrom different point of view- the divine unity. Chapter 139 addresses Proclus' polytheism and his admission of a series of other entities through which causality occurs. Against this, chapter 139 remarks that God is the only cause of the universe. Chapter 146 starts with the citation from Gregory of Nazianzus (Oratio $29.2, P G 36,76 \mathrm{~B}$ ) on the nature of the intratrinitarian procession as the only case of procession where the cause and the effects remain one. This text went, according to Argyros, in the direction of defending God's substantial unity within the process of causation. Argyros' exploitation of these two fragments from the Refutatio Procli is therefore consistent with one of the main arguments brought forth by Argyros' master, Nikephoros Gregoras, namely that separating God's substance and his energies would admit a form of Neoplatonic polytheism. ${ }^{149}$ Taking a cue from Nicholas' critique of Proclus' polytheism, Argyros believes he can adapt Nicholas' refutation to his own critique of Palamas' distinction between God's substance and his providential energies, as if this latter view introduces entities other than God as responsible for the causation process.

At the end of this excursus on Argyros' modus operandi, we can infer that in all probability the attribution to Procopius of chapters 139 and 146 of the Refutatio Procli found in the Vatican manuscripts originated in the fourteenth

\footnotetext{
146 Cf. supra p. 125

147 See Candal 1957, p. 106, l. 21-108, 1. 3, Bianconi 2008, p. 363-364 and Polemis 2012, p. 9o-91, cap. 35 , 1. 2-16.

148 See Russell 2017.

149 Cf. Nikephoros Gregoras, Byzantina Historia, p. 481.5-483.11. We are grateful to Börje Bydén for alerting us to this passage.
} 
century, at the time of the hesychast controversy. At this time, scholars involved in the controversy, such as Argyros, produced anthologies and florilegia containing theological texts which could be used against opposing parties. Within this process, we believe that for reasons probably relating to a mechanical error, someone extracted the fragments of the Refutatio Procli and improperly ascribed it to Procopius. This is not unlikely if one takes into account the fact that in several of these anthologies, such as Ms Vallicellianus F 30 , the various excerpts are transmitted as anonymous, thus making it easier for a scribe to misattribute. Furthermore, as we will show in our conclusions, the tradition of Nicholas' Refutatio Procli includes an acephalous version of the text, something which once again could possibly explain a later misattribution. In this regard, it is our intention to investigate more closely in the future the aforementioned fourteenth-century anti-Palamite anthologies in order to detect further elements favoring this view.

\section{Conclusions}

Two fragments of the Refutatio Procli, a refutation of Proclus' Elements of Theo$\operatorname{logy}$, attributed in the manuscript tradition of the text to the twelfth-century learned bishop Nicholas of Methone, have been ascribed in two fourteenthcentury manuscripts, copied by the byzantine scribe and scholar Isaak Argyros, to the late-ancient Christian rhetor and ecclesiastical writer Procopius of Gaza. On this basis, from the late nineteenth-century until recent years Procopius scholars have blindly accepted Argyros' attribution of the fragments to Procopius and, accordingly, have argued that Nicholas has re-elaborated and even plagiarized a now lost Refutatio Procli by Procopius, of which the two aforementioned fragments are the last surviving traces.

In this paper we provide a complete and balanced account by comparing for the first time historical, philological and paleographical data. An unbiased analysis of the extant data suggests that the attribution to Procopius of the two fragments is probably wrong and, therefore, it is highly improbable that Procopius of Gaza ever authored a Refutation of Proclus' Elements of Theology. One reasonable explanation for a scribal mistake has already been brought forth by Mercati and more recently by Bianconi. According to these scholars, Argyros probably had at his disposal a codex in which the Refutatio Procli was either wrongly attributed to Procopius or was transmitted as anepigraphic and anonymous together with a Procopian text. The only advantage of this solution is that such a codex exists and, more importantly, it surely circulated in the circle of Argyros and his collaborators, as demonstrated by the presence of 
the book-hand of one of Argyros' fellows. ${ }^{150}$ The Ms in question is Vat. gr. 626, a codex copied at the beginning of fourteenth-century and divided into two units preserving Theodoret of Cyrrhus' Graecarum affectionum curatio (f. 1120) and Nicholas' Refutatio Procli (f. 121-212), respectively. The attribution of the Refutatio to Nicholas at f. 121 is due to a later hand, thus suggesting that an anepigraphic copy of the Refutatio Procli circulated among Argyros and his collaborators. At the present stage of research it is not possible to ascertain whether this circumstance alone explains Argyros' attribution to Procopius of chapters 139 and 146 of the Refutatio Procli, or whether Argyros inherited this attribution from a hitherto unknown florilegium which he used as a source. We can only suggest that the attribution to Procopius of the fragments in question must be taken with the greatest caution and that, in absence of new incontrovertible evidence, this attribution must be regarded as highly dubious.

\section{Bibliography}

\section{Manuscripts Consulted}

El Escorial, Real Biblioteca del Monasterio

Y III 21

Firenze, Biblioteca Medicea Laurenziana

Plut. 28.13

Plut. 56.14

Plut. 89 sup. 48

Napoli, Biblioteca Nazionale

III D 37

Nürnberg, Stadtbibliothek

Cent. v App. 36

Cent. v App. 37

Cent. v App. 38

Paris, Bibliothèque nationale de France

gr. 940

gr. 1246

gr. 1276

gr. 1672

gr. 1853

gr. 2507

150 Bianconi 2008, p. 354. 
gr. $275^{8}$

gr. 2821

Parma, Biblioteca Palatina

Parm 154

Prague, Národní Knihovna, XxV. C. 31

Roma

Biblioteca Angelica, gr. 43

Biblioteca Vallicelliana, F. 30

Vaticano (Città del), Biblioteca Apostolica

gr. 81

gr. 573

gr. 604

gr. 626

gr. 678

gr. 1094

gr. 1096

gr. 1102

gr. 1115

gr. 1721

gr. 2335

Pal. gr. 174

Venezia, Biblioteca Nazionale Marciana

gr. 155

gr. 162

gr. 308

gr. 310

gr. 323

\section{Primary Sources}

A Patristic Greek Lexicon, ed. G.W.H. Lampe, Oxford, Oxford University Press, 1961.

Anna Komnene, Alexias, ed. A. Kambylis, D.R. Reinsch, Berlin / New York, De Gruyter, 2001.

Atticus, Fragments, ed. E. Des Places, Paris, Les Belles Lettres, 1977.

Bibliotheca Ecclesiastica, ed. A.K. Demetrakopoulos, Leipzig, Otto Bigand, 1866.

Clavis Patrum Graecorum, ed. M. Geerard, III, Turnhout, Brepols, 1979.

Codices Vaticani Graeci III. Codices 604-866, ed. R. Devreesse, Città del Vaticano, in Biblioteca Apostolica Vaticana, 1950.

Choricius of Gaza, Opera, ed. R. Foerster, E. Richtsteig, Leipzig, Teubner, 1929.

George Tornikès, A Funeral Oration on Anna Komnene, in George et Dèmètrios Tornikès, Lettres et discours, ed. J. Darrouzès, Paris, C.N.R.S, 1970. 
Gregory of Nazianzus, Oratio 39, in Opera, ed. J.P. Migne (Patrologia Graeca 36), Paris, $185^{8}$.

Isaak Argyros see Candal 1957.

John Italos, Quaestiones Quodlibetales, ed. P.-P. Joannou, Ettal, Buch-Kunstverlag, 1956. John Italos, Lettres et discours, ed. P. Gautier, Paris, Institut Français d'études byzantines, 1972.

John Philoponus, In Aristotelis De anima libros commentaria, ed. M. Hayduck, Berlin, G. Reimeri, 1897 .

Lucian of Samosata—Scholia, ed. K. Jacobitz, v. I-IV, Leipzig, Koehler, 1836-1841.

Lucian of Samosata-see also Rabe 1906.

Michael Psellos, Theologica, ed. P. Gautier, Leipzig, Teubner, 1989.

Michael Psellos, Opuscula psychologica, theologica, daemonologica, ed. D. O'Meara, Leipzig, Teubner, 1989 .

Michael Psellos, Philosophica Minora. Opuscula logica, physica, allegorica et alia, ed. J.M. Duffy, vol. I, Leipzig, Teubner, 1992.

Michael Psellos, Orationes forenses et acta, ed. G. Dennis, Stuttgart / Leipzig, Teubner, 1994.

Michael Psellos, Chronographia, ed. D.R. Reinsch, Berlin / Boston, De Gruyter, 2014.

Nicholas of Methone, Refutatio Institutionis Theologicae Procli Platonicis, ed. J.Th. Voemel, in F. Creuser, Initia Philosophiae ac Theologiae ex Platonicis fontibus ducta, IV, Frankfurt, 1825 .

Nicholas of Methone, Refutation of Proclus' Elements of Theology. A critical edition with an introduction on Nicholas' life and works, ed. A.D. Angelou, Athens / Leiden, Academy of Athens / Brill, 1984.

Nikephoros Gregoras, Byzantina Historia, ed. I. Bekker, L. Schopen, vol. 3, Bonnae, Impensis Ed. Weberi, 1855 .

Photius, Bibliotheca, ed. R. Henry, Paris, Les Belles Lettres, 1959.

Procopius of Gaza, Opuscula rhetorica et oratoria, ed. E. Amato, G. Ventrella, Berlin / New York, Teubner, 2009.

Proclus, The Elements of Theology, ed. E.R. Dodds, Oxford, Oxford University Press, 1963. Simplicius, In libros Aristotelis De anima commentaria, ed. M. Hayduck, Berlin, G. Reimeri, 1889 .

Simplicius, On Aristotle on the Soul 3.6-13, ed. C. Steel, London, Bloomsbury, 2003.

Theologica Varia inedita saeculi XIV, ed. I.D. Polemis, Turnhout, Brepols, 2012.

Procopius of Gaza, Commentary on Genesis-Prokop von Gaza: Eclogarum in libros historicos Veteris Testamenti epitome. Teil ı: Der Genesiskommentar, ed. K. Metzler, Berlin / Munich / Boston, De Gruyter, 2015.

Procopius of Gaza, Discours et fragments, ed. E. Amato, Paris, Les Belles Lettres, 2014. Ptolemy, Harmonics in Düring, I. (1930), Die Harmonielehre des Klaudios Ptolemaios, Göteborg, Göteborgs Högskolas Arsskrift. 


\section{Secondary Sources}

Alexidze, L. (2014), "Ioane Petritsi”, in S. Gersh (ed.), Interpreting Proclus: from Antiquity to Renaissance, Cambridge, Cambridge University Press, p. 229-244.

Aly, W. (1957), "Prokopios von Gaza," in Realencyclopädie der classischen Altertumswissenschaft XXIII/1, coll. 259-273.

Amato, E. (2010a), "Sul discusso plagio della Refutatio Procli Institutionis theologicae di Procopio di Gaza ad opera di Nicola di Metone: nuovi apporti della tradizione manoscritta", in Medioevo Greco 10, p. 5-12.

Amato, E. (2010b), "Procopios de Gaza," in R. Goulet (ed.), Dictionnaire des philosophes antiques, v, Paris, CNRS, p. 1675-1691

Amato, E. (2014), "Introduction générale" see Procopius of Gaza.

Bianconi, D. (2008) "La controversia palamitica. Figure, libri, testi, mani," in Segno e Testo 6, p. 337-376.

Bianconi, D. (2015), "Restauri, integrazioni, implementazioni. Tra storia dei libri e storia dei testi greci," in L. Del Corso, F. De Vivo, A. Stramaglia (eds), Nel segno del testo. Edizioni, materiali e studi per Oronzo Pecere, Firenze, Edizioni Gonnelli, p. 239291.

Boeri, M.D. (2009), "Pseudo-Justin on Aristotelian Cosmology: A Byzantine Philosopher Searching for a New Picture of the World," in Byzantion 79, p. 99-135.

Browning, R. (1961), "A New Source on Byzantine Hungarian Relations in Twelfth Cen-

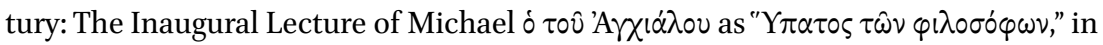
Balkan Studies 2, p. 173-214, 19o. [Repr. as Essay IV in R. Browning, Studies on Byzantine History, Literature and Education, London, Variorum Reprints, 1977].

Candal, M. (1957), "Argiro contra Dexio (Sobra la luz tabórica)," in Orientalia Christiana Periodica 23, p. 80-113

Champion, M.W. (2014), Explaining the Cosmos. Creation and Cultural Interaction in Late-Antique Gaza, Oxford, Oxford University Press.

Chauvot, A. (1986), Procope de Gaza, Priscien de Caesarée. Panégiriques pour l'empereur Anastase I ${ }^{\text {er }}$, Bonn, Habelt.

Chlup, R. (2012), Proclus. An Introduction, Cambridge, Cambridge University Press.

Clucas, L. (1981), The Trial ofJohn Italos and the Crisis of Intellectual Values in Byzantium in the Eleventh Century, Munich, Institut für Byzantinistik, Neugriechische Philologie und Byzantinische Kunstgeschichte der Universität München.

Draeseke, J. (1888), “Zu Nicholas von Methone," in Zeitschrift für Kirchengeschichte 9, p. $405^{-431 .}$

Draeseke, J. (1891), “Zwei Beistreter des Proklos,” in Archiv für Geschichte der Philosophie 4, p. 243-250.

Draeseke, J. (1892), "Nikolaos von Methone," in Byzantinische Zeitschrift 1, p. 438-478.

Draeseke, J. (1895), "Nicholas von Methone als Bestreiter des Proklos," in Theologische Studien und Kritiken 68, p. 589-616. 
Draeseke, J. (1897), "Prokopios' von Gaza Widerlegung des Proklos," in Byzantinische Zeitschrift 6, p. 55-91.

Düring 193 o see Ptolemy.

Felmy, K.C. (2011), "The Development of the Trinity Doctrine in Byzantium (Ninth to Fifteenth Centuries)," in G. Emery, M. Levering (eds), The Oxford Handbook of the Trinity, Oxford, Oxford University Press, p. 210-222.

Gioffreda, A. (2020), Tra i libri di Isacco Argiro, de Gruyter, Berlin / Boston.

Golitsis, P. (2014), Trois annotations de manuscrits aristotéliciens au XII ${ }^{e}$ siècle: les Parisini gr. 1902 et 1853 et l'Oxoniensis Corp. Christ. 108, in D. Bianconi (ed), Storia della scrittura e altre storie, Roma, Bollettino dei classici, Supplemento 29, p. 33-52.

Gouillard, J. (1985), "Le procès officiel de Jean l'Italien. Les actes et leur sous-entendus," in Travaux et Mémoires 9, p. 133-174.

Guillou, A. (1995), "Le monastère de la Théotokos au Sinai. Origines; épiclèse; mosaique de la Trasfiguration; Homélie inédite d'Anastase le Sinaite sur la Trasfguration," in Mélanges d'Archéologie et d'Histoire 67, p. 215-256.

Günther, H.-Ch. (2007), Die Übersetzungen der Elementatio theologica des Proklos und ihre Bedeutung für den Proklostext, Leiden, Brill.

Hofstetter, C. (2018), "Le mystérieux Soterichos: contribution à l' établissement de l'histoire du texte d'un commentaire byzantin à la psychogonie de Platon," in Revue d'histoire des textes 13, p. 59-91.

Jeck, U.R. (2015), "Friedrich Creuzers und Johann Theodor Voemels byzantinistische Impulse. Dokumente zu Entstehung und früher Wirkungsgeschichte der Editio princeps der Refutatio institutionis theologicae Procli Platonici des Nikolaos von Methone," in Bochumer Philosophisches Jahrbuch für Antike und Mittelalter 18/1, p. 164-194.

Kazdhan, A.P., Epstein, A.Wh. (1985), Change in Byzantine Culture in the Eleventh and Twelfth Centuries, Berkley / Los Angeles / London, University of California Press.

Krumbacher, K. (1897 $)$, Geschichte der byzantinischen Literatur von Justinian bis zum Ende des östromische Reiches (527-1453), München, Beck.

Laue W., Makris G. (2002), "Isaac Argyros' Abhandlung über die Kegelprojektion I in der Geographia des Klaudios Ptolemaios," in Palaeoslavica 10, p. 226-245.

Magdalino, P. (1993), The Empire of Manuel Komnenos 1143-1180, Cambridge, Cambridge University Press.

Mai, A. (1831), Classicorum auctorum e vaticanis codicibus editorum, t. IV. Complectens scripta aliquot Oribasii, Procopii, Isaei, Themistii, Porphyrii, Philonis, Aristidis, et alia quaedam, Romae, Typis Vaticanis.

Maltese, E.V. (1996), "La teologia bizantina nell'undicesimo secolo fra spiritualità monastica e filosofia ellenica," in G. D'Onofrio (ed.), Storia della teologia nel Medioevo, I, Casale Monferrato, Piemme, p. 555-587.

Martini, E. (1902), Catalogo dei manoscritti greci esistenti nelle biblioteche italiane, Milano, Istituto Poligrafico dello Stato. 
Matino, G. (2005), Procopio di Gaza. Panegirico per l'imperatore Anastasio, Napoli, Giannini.

Mercati, G. (1931), Notizie di Procoro e Demetrio Cidone, Manuele Caleca e Teodoro Meliteniota ed altri appunti per la storia della teologia e della letteratura bizantina del secolo XIV, Città del Vaticano, Biblioteca Apostolica Vaticana.

Mondrain, B. (2008), "Les écritures dans les manuscrits byzantins du XIV e siècle," in Rivista di studi bizantini e neoellenici 44, p. 157-196.

Moore, P. (2005), Iter Psellianum. A Detailed Listing of Manuscript Sources for all Works Attributed to Michael Psellos. Including a Comprehensive Bibliography, Toronto, Pontifical Institute of Medieval Studies.

O'Meara, D. (2013), "Psellos' Commentary on the Chaldean Oracles and Proclus' lost Commentary," in H. Senf (ed.), Platonismus und Esoterik in Byzantinischem Mittelalter und italienischer Renaissance, Heidelberg, p. 48-58.

O'Meara, D. (2014), "Michael Psellos," in S. Gersh (ed.), Interpreting Proclus: From Antiquity to Renaissance, Cambridge, Cambridge University Press, p. 165-180.

Pérez Martín, I. (2008), “El 'estilo hodegon' y su proyección en las escrituras constantinopolitanas," in Segno e Testo 6, p. 389-458.

$P L P=$ Trapp, E. (1976-1996), Prosopographische Lexikon der Palaiologenzeit, Vienna, Verlag der Österreichischen Akademie der Wissenschaften.

Podskalsky, G. (1976), "Nikolaos von Methone und die Proklosrenaissance in Byzanz," in Orientalia christiana periodica 42, p. 509-523.

Polemis, I.D. (1993), "Arsenius of Tyrus and his Tome against the Palamites," in Jahrbuch der Österreichischen Byzantinistik 43, p. 241-282.

Polemis, I.D. (2011), "Notes on the Inaugural Oration of the Patriarch Michael of Anchialos," in Byzantinoslavica 69, p. 162-172.

Polemis, I.D. (2012) see Theologica Varia inedita

Rigo, A. (1987-1989), "Noterelle in margine alla controversia palamitica," in Miscellanea Marciana II-IV, p. 126-129.

Rigo, A. (1989), Monaci esicasti e monaci bogomili. Le accuse dimessalianesimo e bogomilismo rivolte agli esicasti ed il problema dei rapporti tra esicasmo e bogomilismo, Firenze, Olschki.

Rigo, A. (2012), "De l'apologie à l'évocation de l'éxperience mystique. Évagre le Pontique, Isaac le Syrien et Diadoque de Photicé dans les œvres de Grégoire Palamas (et dans le controversée palamite)," in A. Speer, Ph. Steinkrüger (eds), Knotenpunkt Byzanz. Wissenformen und kulturelle Wechselbeziehungen, Berlin / Boston, De Gruyter, p. 85-110.

Robinson, J. (2014), Nicholas of Methone's Refutation of Proclus: Theology and Neoplatonism in 12th-century Byzantium, Unpublished Doctoral Dissertation, Notre Dame, Indiana.

Robinson, J. (2017), "Proclus as Heresiarch: Theological Polemic and Philosophical 
Commentary in Nicholas of Methone's Refutation (Anaptyxis) of Proclus' Elements of Theology," in S. Mariev (ed.), Byzantine Perspectives on Neoplatonism, Berlin / Boston, de Gruyter, p. 103-136.

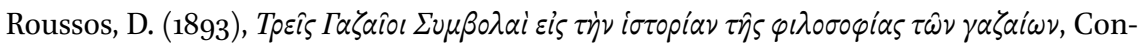
stantinople.

Russell, N. (2017), "The Hesychast Controversy," in A. Kaldellis, N. Sioniossoglou (eds), The Cambridge Intellectual History of Byzantium, Cambridge, Cambridge University Press, p. 494-508

Sicherl, M. (1960), "Michael Psellos und Iamblichos De mysteriis," in Byzantinische Zeitschrift 53/2, p. 8-19.

Siecinski, A.E. (2010), The Filioque: History of a Doctrinal Controversy, Oxford, Oxford University Press.

Sorabji, R. (2015), "Waiting for Philoponus," in A. Marmodoro, B.D. Prince (eds), Causation and Creation in Late-Antiquity, Cambridge, Cambridge University Press, p. 71-93.

Spingou, F. (2017), "A Platonising Dialogue from the Twellfth Century: the Logos of Soterichos Panteugenos," in A.M. Cameron, G. Niels (eds), Dialogues and Debates from Late Antiquity to Late Byzantium, London, Routledge, p. 123-136.

Steel, C. (2003) see Simplicius.

Stiglmayr, J. (1899), "Die Streitschrift des Prokopios von Gaza gegen den Neuplatoniker Proklos," in Byzantinische Zeitschrift 8, p. 263-301.

Tatakis, B. (1949), La philosophie byzantine, Paris, Presses Universitaires de France.

Trizio, M. (2014), "Eleventh- to Twelfth-Century," in S. Gersh (ed.), Interpreting Proclus. From Antiquity to Renaissance, Cambridge, Cambridge University Press, p. 182-215.

Voemel, J.Th. (1825) see Nicolai Methonis Refutatio

Westerink, L.G. (1942), "Proclus, Procopius, Psellus," in Mnemosyne 10 (1942), p. 276-277.

Whittaker, J. (1975), "Proclus, Procopius, Psellus and the Scholia on Gregory Nazianzen," in Vigiliae Christianae 29, p. 309-313. 